\title{
Hydrogeology and Analysis of Aquifer Characteristics in West-Central Pinellas County, Florida
}

By James C. Broska and Holly L. Barnette

U.S. Geological Survey

Open-File Report 99-185

Prepared in cooperation with

PINELLAS COUNTY

Tallahassee, Florida 1999

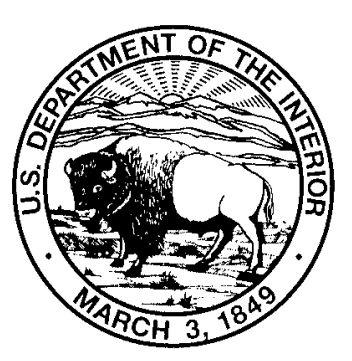




\title{
U.S. DEPARTMENT OF THE INTERIOR BRUCE BABBITT, Secretary
}

\author{
U.S. GEOLOGICAL SURVEY
}

Charles G. Groat, Director

For additional information write to:

District Chief

U.S. Geological Survey

Suite 3015

227 North Bronough St.

Tallahassee, FL 32301
Copies of this report can be purchased from:

U.S. Geological Survey Branch of Information Services Box 25286

Denver, CO 80225 888-ASK-USGS 


\section{CONTENTS}

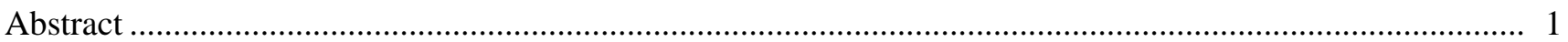

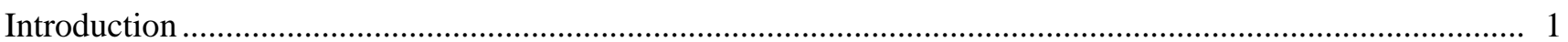

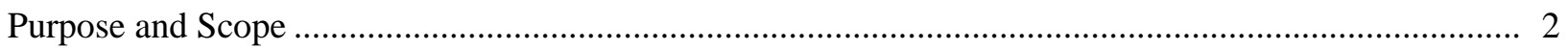

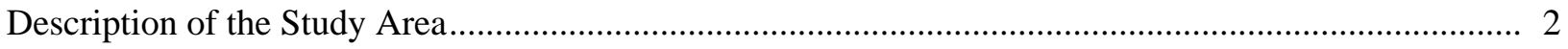

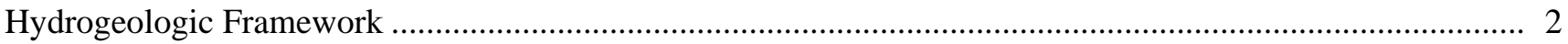

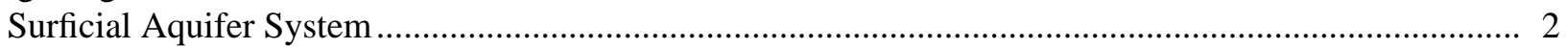

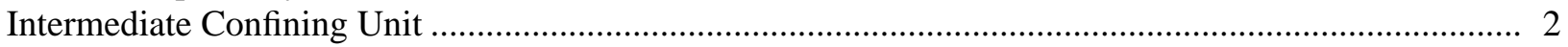

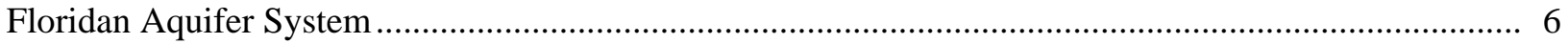

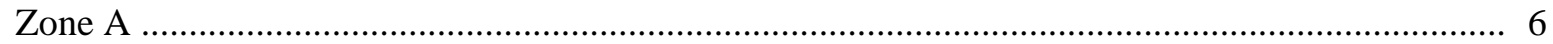

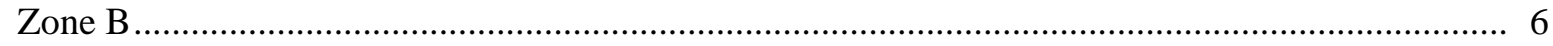

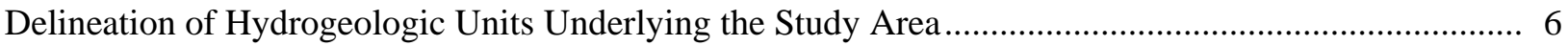

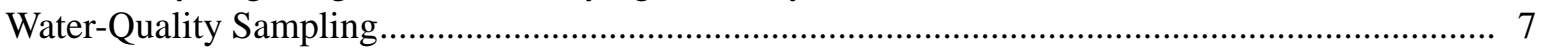

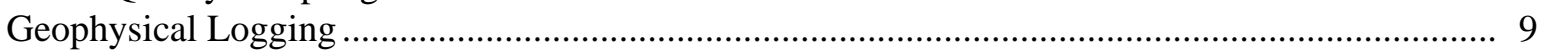

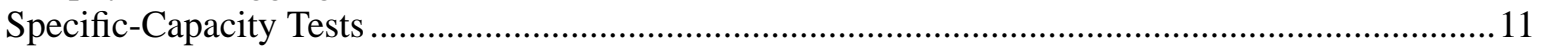

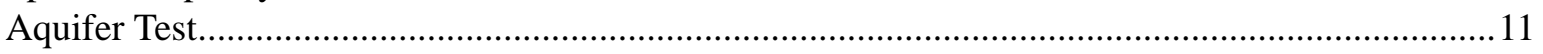

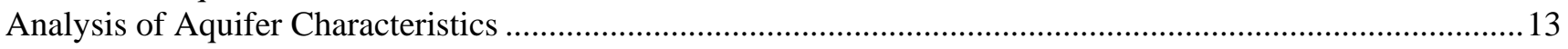

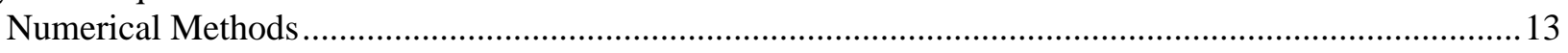

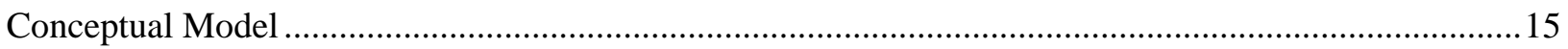

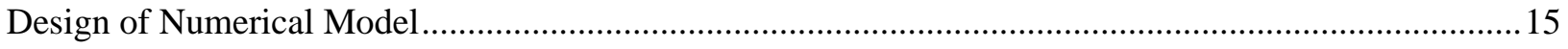

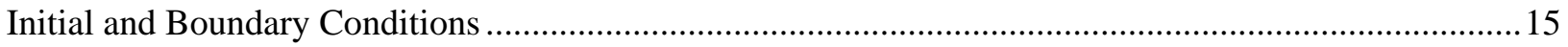

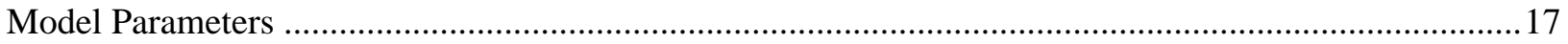

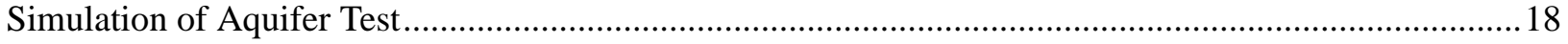

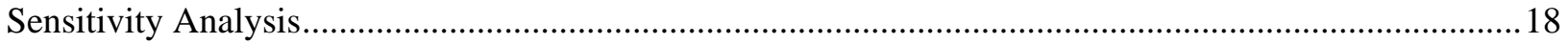

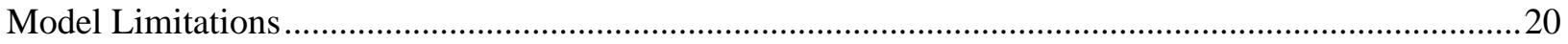

Summary …

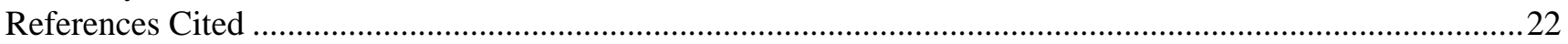

Figures

1. Map showing location of the study area in west-central Pinellas County, well names, and hydrogeologic section $A-A^{\prime}$.

2. Chart showing generalized stratigraphic and hydrogeologic section underlying the Walsingham

Park test site, Pinellas County, and equivalent model units ............................................................. 4

3. Section showing hydrogeologic units underlying the study area correlated to natural-gamma ray $\log$ traces for section $A-A^{\prime}$ in Pinellas County .......................................................................... 5

4. Map showing Walsingham Park test site, including location of wells drilled during the field investigation, and location of off-site monitor well..................................................................... 7

5. Diagram showing generalized section view of casing depths and final depths of wells at the

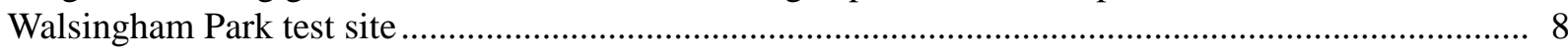

6-10. Graphs showing:

6. Relation of dissolved solids and depth from water samples collected during drilling of Walsingham Park deep exploratory well (WPMW-1)......

7. Relation between dissolved solids and specific conductance of selected water samples collected during drilling of Walsingham Park deep exploratory well (WPMW-1) ..................................... 9

8. Geophysical logs of Walsingham Park deep exploratory well (WPMW-1)................................... 10 
9. Water levels in all monitor wells before, during, and after the 9-day aquifer test

10. Changes in specific conductance during the 9-day aquifer test at Walsingham Park Test

Production Well and Walsingham Park Monitor Wells 1 and 2

11. Section showing model grid, simulated open-hole intervals, and boundary conditions used in the HST3D simulation.

12-14. Graphs showing:

12. Simulated and observed water levels during drawdown and recovery periods at selected wells during the 9-day aquifer test. 19

13. Simulated and observed water levels in selected monitor wells during the 9-day aquifer test ....... 20

14. Sensitivity of simulated water levels to changes in selected model input parameters

\section{Tables}

1. Results from specific capacity and packer tests from the deep exploratory well

2. Values for model parameters used to establish initial conditions and values for calibrated model parameters

3. Simulated and corrected observed drawdown and recovery for selected monitor wells during the

9-day aquifer test 


\section{CONVERSION FACTORS, VERTICAL DATUM, AND ADDITIONAL ABBREVIATIONS}

\begin{tabular}{lcl}
\hline \multicolumn{1}{c}{ Multiply inch-pound unit } & By & \multicolumn{1}{c}{ To obtain } \\
\hline inch per year (in/yr) & 25.4 & millimeter per year \\
inches squared per pound $\left(\mathrm{in}^{2} / \mathrm{lb}\right)$ & $1.45 \times 10^{-4}$ & square meter per Newton \\
foot $(\mathrm{ft})$ & 0.3048 & meter \\
foot per day (ft/d) & 0.3048 & meter per day \\
foot per day per foot $(\mathrm{ft} / \mathrm{d}) / \mathrm{ft}$ & 0.3048 & meter per day per meter \\
foot squared per day $\left(\mathrm{ft}^{2} / \mathrm{d}\right)$ & 0.093 & meter squared per day \\
cubic feet per day $\left(\mathrm{ft}^{3} / \mathrm{d}\right)$ & 0.02832 & cubic meter per day \\
pound per cubic foot $\left(\mathrm{lb} / \mathrm{ft}^{3}\right)$ & 16.02 & kilogram per cubic meter \\
gallon per minute $(\mathrm{gal} / \mathrm{min})$ & 5.45 & cubic meter per day \\
million gallons per day $(\mathrm{Mgal} / \mathrm{d})$ & 0.04381 & cubic meters per second \\
& & \\
\hline
\end{tabular}

Temperature can be converted between degrees Fahrenheit $\left({ }^{\circ} \mathrm{F}\right)$ and degrees Celsius $\left({ }^{\circ} \mathrm{C}\right)$ as follows:

$$
\begin{gathered}
{ }^{\circ} \mathrm{F}=9 / 5\left({ }^{\circ} \mathrm{C}\right)+32 \\
{ }^{\circ} \mathrm{C}=5 / 9\left({ }^{\circ} \mathrm{F}-32\right)
\end{gathered}
$$

Sea level: In this report, "sea level" refers to the National Geodetic Vertical Datum of 1929 (NGVD of 1929)a geodetic datum derived from a general adjustment of the first-order level nets of the United States and Canada, formerly called Sea Level Datum of 1929.

\section{ADDITIONAL ABBREVIATIONS}

$$
\begin{aligned}
& \mathrm{ICU}=\text { Intermediate confining unit } \\
& \mathrm{SAS}=\text { Surficial aquifer system } \\
& \mathrm{LZA}=\text { Lower Zone A } \\
& \mathrm{UZA}=\text { Upper Zone A } \\
& \mathrm{USGS}=\text { U.S. Geological Survey } \\
& \mathrm{mg} / \mathrm{L}=\text { milligrams per liter } \\
& \mu \mathrm{S} / \mathrm{cm}=\text { microsiemens per centimeter }
\end{aligned}
$$


VI Contents 


\title{
Hydrogeology and Analysis of Aquifer Characteristics in West-Central Pinellas County, Florida
}

\author{
By James C. Broska and Holly L. Barnette
}

\section{ABSTRACT}

The U.S. Geological Survey, in cooperation with Pinellas County, Florida, conducted an investigation to describe the hydrogeology and analyze the aquifer characteristics in west-central Pinellas County. A production test well and four monitor wells were constructed in Pinellas County at Walsingham Park during 1996-97. Water-quality sampling, static and dynamic borehole geophysical surveys, and hydraulic tests were conducted at the wells to delineate the hydrogeology at Walsingham Park. A 9-day aquifer test was conducted to determine the hydraulic characteristics of the aquifer system and observe the changes in water quality due to pumping.

A numerical model was constructed to simulate the aquifer test and calculate values for hydraulic conductivity and storage coefficient for permeable zones and confining units at Walsingham Park. Final calibrated values for hydraulic conductivity for the different permeable zones and confining units at the test site were 18 feet per day for Upper Zone A, 750 feet per day for Lower Zone A, 1 foot per day for Zone B, $1 \times 10^{-4}$ feet per day for the intermediate confining unit, and 10 feet per day for the semiconfining unit separating Upper Zone A and Lower Zone A. Final calibrated values for storage coefficient were $3.1 \times 10^{-4}$ for Upper Zone A, $8.6 \times 10^{-5}$ for Lower Zone A, $2.6 \times 10^{-5}$ for Zone B, $3.1 \times 10^{-4}$ for the intermediate confining unit, and $4.3 \times 10^{-5}$ for the semiconfining unit separating Upper Zone A and Lower Zone A. Estimates of transmissivity for Upper Zone A and Lower Zone A were about 2,500 and 37,500 feet squared per day, respectively.

\section{INTRODUCTION}

Pinellas County, located in west-central Florida, has limited potable water supplies and is dependent on water delivered from Tampa Bay Water (formerly called the West Coast Regional Water Supply Authority) which withdraws water from neighboring inland counties to meet the water demands of a large population. Although the population of Pinellas County has not increased significantly since 1990 , during the period from 1970 to 1990 the population of Pinellas County increased from 552,329 to 851,659 (University of Florida, 1991). In 1990, the county received a total of $78 \mathrm{Mgal} / \mathrm{d}$ of water from Hillsborough and Pasco Counties (Marella, 1992). To alleviate some of the demand for this delivered water, Pinellas County is exploring the possibility of using the brackish-water resources within the Upper Floridan aquifer underlying the county.

Brackish waters (water with dissolved-solids concentrations between 1,000 and 10,000 mg/L) are found in the Upper Floridan aquifer at depths ranging from about 100 to $400 \mathrm{ft}$ below land surface in central Pinellas County (Cherry and others, 1970). The development of these brackish-water resources through low-pressure reverse osmosis could provide a source of potable water. Low-pressure reverse osmosis is a process of forcing water through a membrane to remove dissolved solids, thus purifying the water; however, the process is economically practical only when dissolved-solids concentrations are less than 7,000 mg/L (D. Slonena, Pinellas County Utilities, written commun., 1998).

A production test well and four monitor wells were constructed in 1996-97 at Walsingham Park in west-central Pinellas County. The wells were subjected to various geologic investigation methods to determine the hydrogeology at the test site and the viability of brackish-water development in the area. 


\section{Purpose and Scope}

This report presents the results of a study by the U.S. Geological Survey (USGS), in cooperation with Pinellas County, to evaluate the brackish-water resources underlying the Walsingham Park study area in west-central Pinellas County. Results from the field investigation and numerical simulation to determine aquifer characteristics at the Walsingham Park test site could provide valuable information for future development of brackish water in Pinellas County and in other coastal counties in west-central Florida. The report includes: descriptions of the hydrogeologic framework of the study site, hydraulic characteristics of the aquifer system, and description of the ground-water quality.

The objectives of this report are to

1.) describe the hydrogeology at the test site, and

2.) evaluate an aquifer test conducted in the Upper Floridan aquifer at the test site.

\section{Description of the Study Area}

Pinellas County is a peninsula in west-central Florida bounded by Tampa Bay to the east and the Gulf of Mexico to the west (fig. 1). The county is part of the Gulf Coastal Lowlands physiographic region described by White (1970) which consists of low angle scarps and terraces formed during several Pleistocene sea-level stands. The climate of Pinellas County is subtropical with an average rainfall of 53 inches per year (in/yr). Most rainfall occurs during the summer months between June and September (Causseaux and Fretwell, 1983). Land surface elevation at the Walsingham Park test site is about $55 \mathrm{ft}$ above sea level.

\section{HYDROGEOLOGIC FRAMEWORK}

The geology of Florida consists of a pre-Mesozoic igneous and metamorphic basement and an overlying thick sequence of sedimentary units deposited during transgressive and regressive episodes (Heath and Smith, 1954). The hydrogeologic framework underlying the study area consists of Eocene or younger-age rocks and makes up the surficial aquifer system, the intermediate confining unit, and the Floridan aquifer system (fig. 2). This multilayered system consists of several permeable zones interbedded with zones of variable permeability that function as either confining units or semiconfining units. A semiconfin- ing unit in this report refers to lower-permeability carbonate units that do not produce large quantities of water to wells when pumped (Knochenmus and Swenson, 1996). The hydrogeologic information compiled from wells at the test site was correlated with hydrogeologic information from previous studies in westcentral Pinellas County. A generalized hydrogeologic section, oriented north-south, was constructed from natural-gamma geophysical logs (fig. 3).

\section{Surficial Aquifer System}

The surficial aquifer system (SAS) in Pinellas County is the shallowest water-bearing formation in the study area and consists of undifferentiated sands and clays which change in composition laterally and vertically (Causseaux, 1985). The post-Miocene age surface deposits in Pinellas County lie unconformably above the Hawthorn Group. Surface deposits are characterized by a base of marginal marine beds overlain by sandy, marine terrace deposits and capped by aeolian sand deposits. The thickness of the SAS, which ranges from a few feet to $50 \mathrm{ft}$, restricts the amount of potable water the aquifer supplies; however, the nonpotable water is utilized for irrigation (Gilboy, 1985). The SAS at the Walsingham Park site is about $35 \mathrm{ft}$ thick. Throughout Pinellas County, the water table is less than $15 \mathrm{ft}$ below land surface during dry periods and close to land surface during wet periods. Precipitation is the main source of recharge.

Hydraulic properties of the SAS are highly variable due to the diversity in physical characteristics of the sediments. Grain size, sorting, and thickness vary throughout the system and greatly influence the permeability and porosity of the system. Values for specific yield range from 0.1 to 0.35 (Causseaux, 1985). Horizontal hydraulic conductivity is estimated to range from 13 to $33 \mathrm{ft} / \mathrm{d}$ (Cherry and Brown, 1974; Sinclair, 1974) and vertical hydraulic conductivity is estimated to range from 0.36 to $13 \mathrm{ft} / \mathrm{d}$ (Sinclair, 1974; Hutchinson and Stewart, 1978).

\section{Intermediate Confining Unit}

The surficial and Floridan aquifer systems are separated by the low-permeability intermediate confining unit (ICU). The ICU occurs within the upper Miocene undifferentiated Arcadia Formation of the Hawthorn Group. The formation consists of interbedded quartz sands, clays, and carbonates. The clay beds in the Arcadia Formation act as confining beds 


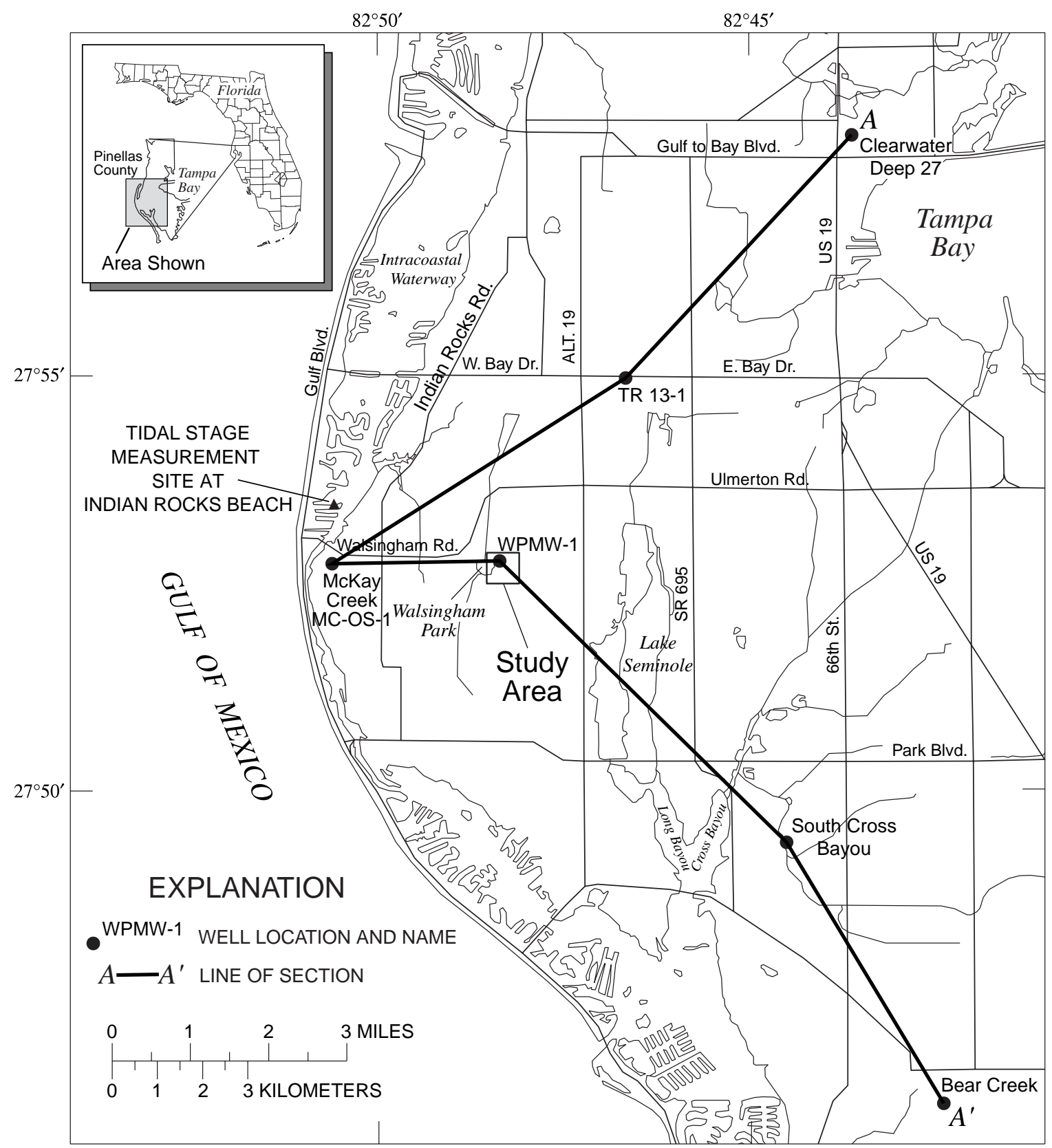

Base from SWFWMD digital data, 1:250,000, 1992

Albers Equal-Area Conic projection

Standard Parallels $29^{\circ} 30^{\prime}$ and $45^{\circ} 30^{\prime}$, central meridian $-83^{\circ} 00^{\prime}$

Figure 1. Location of the study area in west-central Pinellas County, well names, and hydrogeologic section $A-A^{\prime}$.

throughout Pinellas County (Heath and Smith, 1954). The thickness of the ICU averages about $90 \mathrm{ft}$ and ranges from 50 to $140 \mathrm{ft}$. At the Walsingham Park site, the ICU is about $100 \mathrm{ft}$ thick. Due to the heterogeneous nature of the unit, a wide range of hydraulic properties has been reported. Vertical hydraulic con- ductivity for the ICU ranges from $1.3 \times 10^{-4}$ to $6.9 \times 10^{-3}$ ft/d (Sinclair, 1974; Black, Crow and Eidness, Inc., 1978). Leakance values reported in previous investigations range from $1 \times 10^{-5}$ to $1.5 \times 10^{-2}(\mathrm{ft} / \mathrm{d}) / \mathrm{ft}$ (Black, Crow and Eidness, Inc., 1978; Seaburn and Robertson, Inc., 1983; Brown and Associates, Inc., 1986). 


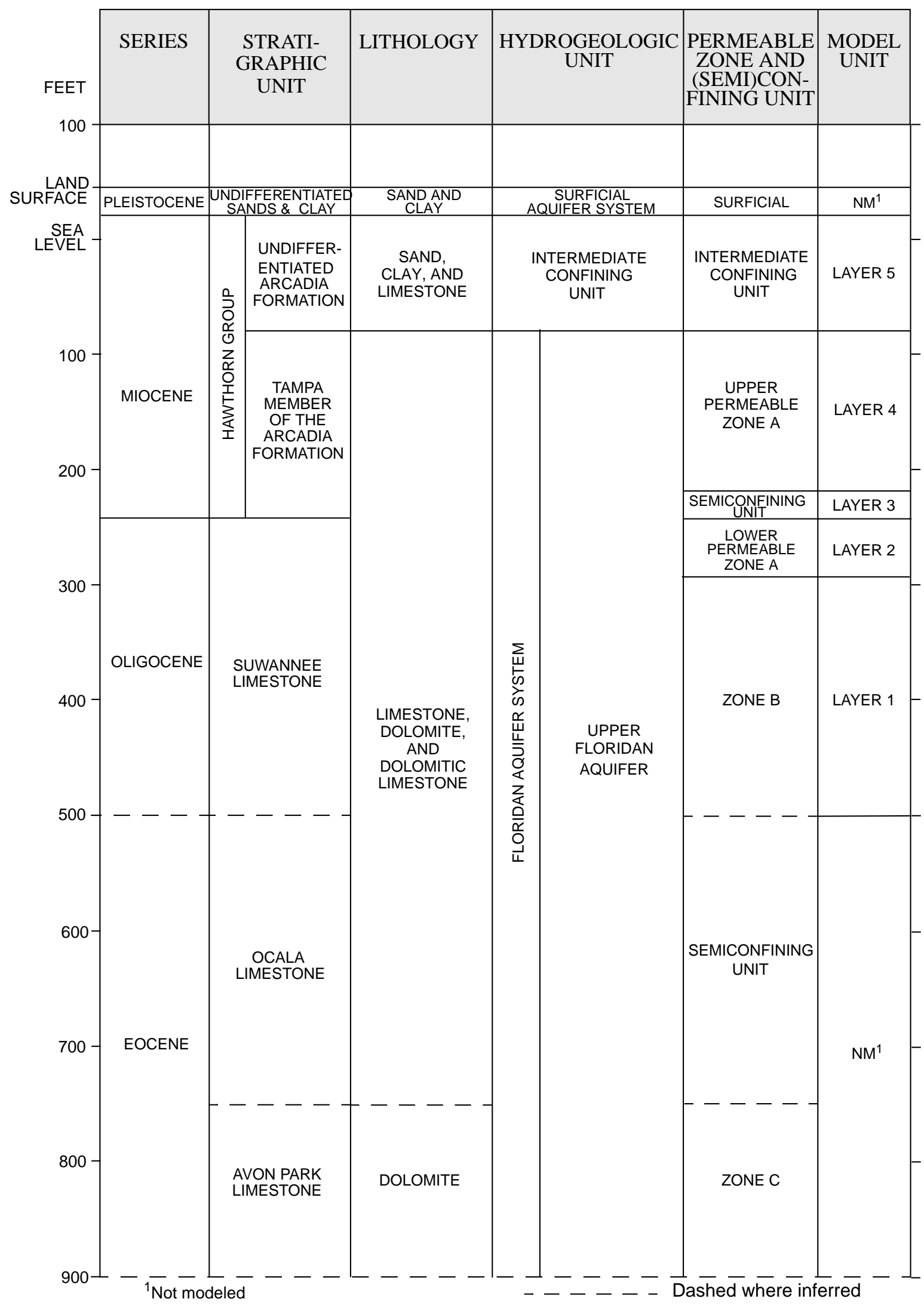

Figure 2. Generalized stratigraphic and hydrogeologic section underlying the Walsingham Park test site, Pinellas County, and equivalent model units (modified from Knochenmus and Swenson, 1996). 


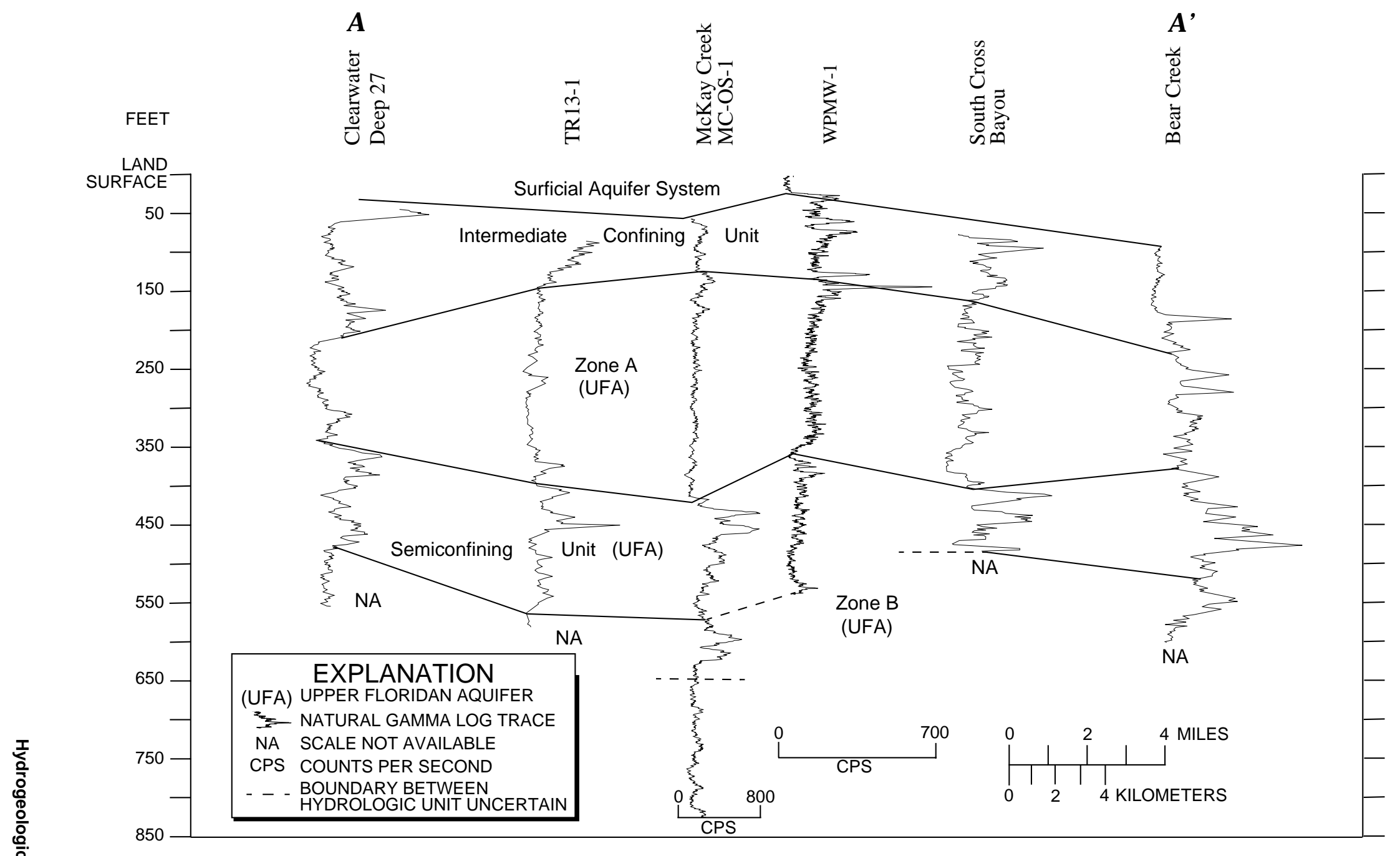

Figure 3. Hydrogeologic units underlying the study area correlated to natural-gamma ray log traces for section $A$ - $A^{\prime}$ in Pinellas County (location of section shown in fig. 1). 


\section{Floridan Aquifer System}

The Floridan aquifer system consists of limestones and dolomites and includes the Upper Floridan aquifer, the middle confining unit, and the Lower Floridan aquifer. The Upper Floridan aquifer in Pinellas County is composed of the Avon Park Formation, the Ocala Limestone, the Suwannee Limestone, and the Tampa Member of the Arcadia Formation (fig. 2). The Avon Park Formation consists of marine limestones interbedded with dolostones. The limestones are predominantly well indurated packstones which are highly fossiliferous. Overlying the Avon Park Formation is the Ocala Limestone. The Ocala Limestone consists of moderately indurated grainstones and packstones. The foraminiferal limestones in the unit commonly contain benthic foraminifera, bryozoan, echinoid, and mollusk fossils. The Ocala Limestone has a gradational contact with the overlying Suwannee Limestone. The Suwannee Limestone is predominantly foraminiferal packstone to grainstone with abundant mollusk and microfaunal remains (Miller, 1986). Overlying the Suwannee Limestone is the Tampa Member of the Arcadia Formation, which is the lower Miocene unit of the Hawthorn Group (Miller, 1986). The Tampa Member lies unconformably on the Suwannee Limestone and consists of limestone with dolostone, sands, and clays present in minor amounts. Mollusks, foraminifera, and algae are the common fossil molds present in the unit. The unit varies from mudstones to packstones, but is predominately wackestones.

In Pinellas County, the Upper Floridan aquifer is subdivided into four permeable zones generally separated by semiconfining units as defined by Hickey (1982). The zones are labeled alphabetically with increasing depth from A to D. The focus of this report is the uppermost part of the Upper Floridan aquifer, specifically the Tampa Member of the Arcadia Formation of the Hawthorn Group (Zone A) and the Suwannee Limestone (Zones A and B) because these are the only zones that contain brackish water at concentrations suitable for low-pressure reverse osmosis. Further discussions will be restricted to Zones A and B.

\section{Zone A}

Zone A, the shallowest and freshest permeable zone in the Upper Floridan aquifer, is made up of the Tampa Member and the upper part of the Suwannee Limestone. In Pinellas County, the thickness of Zone A averages $180 \mathrm{ft}$ and ranges from approximately 115 to
$250 \mathrm{ft}$. Reported transmissivities for Zone A throughout Pinellas County range from 10,000 to $40,000 \mathrm{ft}^{2} / \mathrm{d}$ (Hickey, 1982; Seaburn and Robertson, Inc., 1983; Brown and Associates, Inc., 1986). Values for storativity range from $4 \times 10^{-4}$ to $8 \times 10^{-4}$ (Hickey, 1982). Hickey (1982) divided Zone A into Upper Zone A (UZA) and Lower Zone A (LZA), separated by a discontinuous semiconfining unit. At the Walsingham Park site, a 25-ft thick semiconfining unit consisting of an abundance of marine clay separates the $140 \mathrm{ft}$ thick UZA from LZA, which is about $50 \mathrm{ft}$ thick (fig. 2).

\section{Zone B}

In Pinellas County, Zone B underlies Zone A. Thickness of Zone B averages about $150 \mathrm{ft}$ and ranges from about 125 to $170 \mathrm{ft}$. The upper part of Zone B functions as a semiconfining unit in some parts of Pinellas County and is considered a nonproducing zone in these areas (Hickey, 1982; Knochenmus and Swenson, 1996). Reported hydraulic properties for this sequence are $1.3 \times 10^{-3}$ to $2 \mathrm{ft} / \mathrm{d}$ for vertical hydraulic conductivity, $0.1 \mathrm{ft} / \mathrm{d}$ for horizontal hydraulic conductivity, and $7 \times 10^{-3}(\mathrm{ft} / \mathrm{d}) / \mathrm{ft}$ for leakance (Hickey, 1982; Seaburn and Robertson, Inc., 1983; and Brown and Associates, Inc., 1986). The lower part of Zone B is more permeable and is comprised of the lower part of the Suwannee Limestone. Thickness of this section of Zone B averages about $62 \mathrm{ft}$ and ranges from 50 to $75 \mathrm{ft}$. Transmissivity estimates by Hickey (1982) suggest a value of about $5,000 \mathrm{ft}^{2} / \mathrm{d}$. At the study site, Zone B was encountered between 350 and $547 \mathrm{ft}$ below land surface. However, no apparent changes in permeability in the upper and lower parts of Zone B could be determined during drilling.

\section{Delineation of Hydrogeologic Units Underlying the Study Area}

The delineation of hydrogeologic units and their associated hydraulic properties at the Walsingham Park test site was accomplished through the collection and interpretation of lithologic and stratigraphic data, water-quality data, borehole geophysical data, and hydraulic data. During the well construction, rock core description, discrete water-quality sampling, borehole geophysical logging, and specific capacity tests were performed. Upon completion of the well construction, a 9-day aquifer test was performed. In total, one test production well 3 and four monitor wells were installed at the test site (fig. 4). 


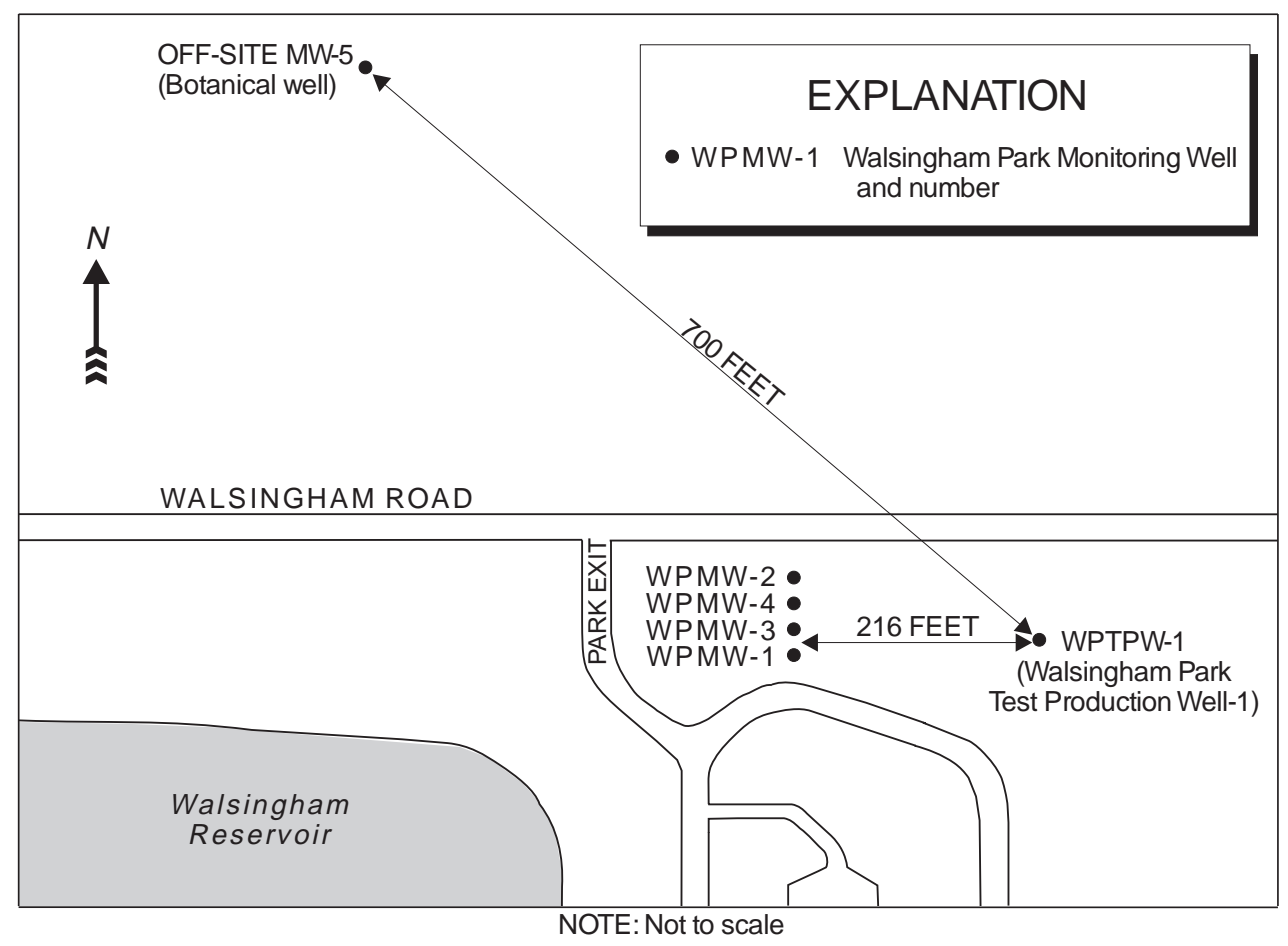

Figure 4. Walsingham Park test site, including location of wells drilled during the field investigation, and location of off-site monitor well (general location is shown in fig. 1).

A production test well and four monitor wells were drilled by using a dual-wall reverse-circulation rotary drilling method. With this drilling method, pressurized air is forced down between the inner and outer barrels of the drilling stem. Rock and/or sediment is cut by the drill bit, and core samples rise to land surface through the inner barrel. The first well drilled was originally designed to function as a deep exploratory well and was drilled to a depth of $547 \mathrm{ft}$. This well was drilled to define the geology, water quality, and vertical distribution of producing zones and confining units at the test site. Data collected from the deep exploratory well were used to determine the total depths and casing depths of the test production well and monitor wells. After drilling and data collection, the deep exploratory well was backplugged to a depth of $266 \mathrm{ft}$ and converted into the Walsingham Park UZA monitor well 1 (WPMW-1). The WPMW-1 and all other monitor wells were constructed to monitor a specific producing zone or lower permeability unit to evaluate the responses of various zones to pumping. The other wells drilled as part of this study are hereafter referred to as the test production well 1 (WPTPW-1), the LZA brackish-water monitor well 2 (WPMW-2), the intermediate confining unit monitor well 3 (WPMW-3), and the surficial aquifer system monitor well 4 (WPMW-4). Total depths and casing depths of all the wells constructed during this study are provided in figure 5 .

\section{Water-Quality Sampling}

Water-quality samples were collected by the USGS and Pinellas County personnel during drilling of WPMW-1 to determine vertical distribution of water quality at the site. Water samples were collected at discrete intervals every $10 \mathrm{ft}$ during drilling and tested onsite for specific conductance, temperature, and $\mathrm{pH}$. When abrupt changes in field measurements occurred, water samples were collected and analyzed for major ions and physical properties at the Pinellas County Utilities laboratory. A vertical water-quality profile showing variations in dissolved solids with depth during drilling of WPMW-1 is presented in figure 6. As illustrated, the dissolved-solids concentration begins increasing approximately $350 \mathrm{ft}$ below land surface. Although some water samples collected between 360 and $425 \mathrm{ft}$ below land surface contained a lower concentration of dissolved solids, this anomaly may have been caused by drilling constraints as water samples were collected over a period of 3 consecutive days. 

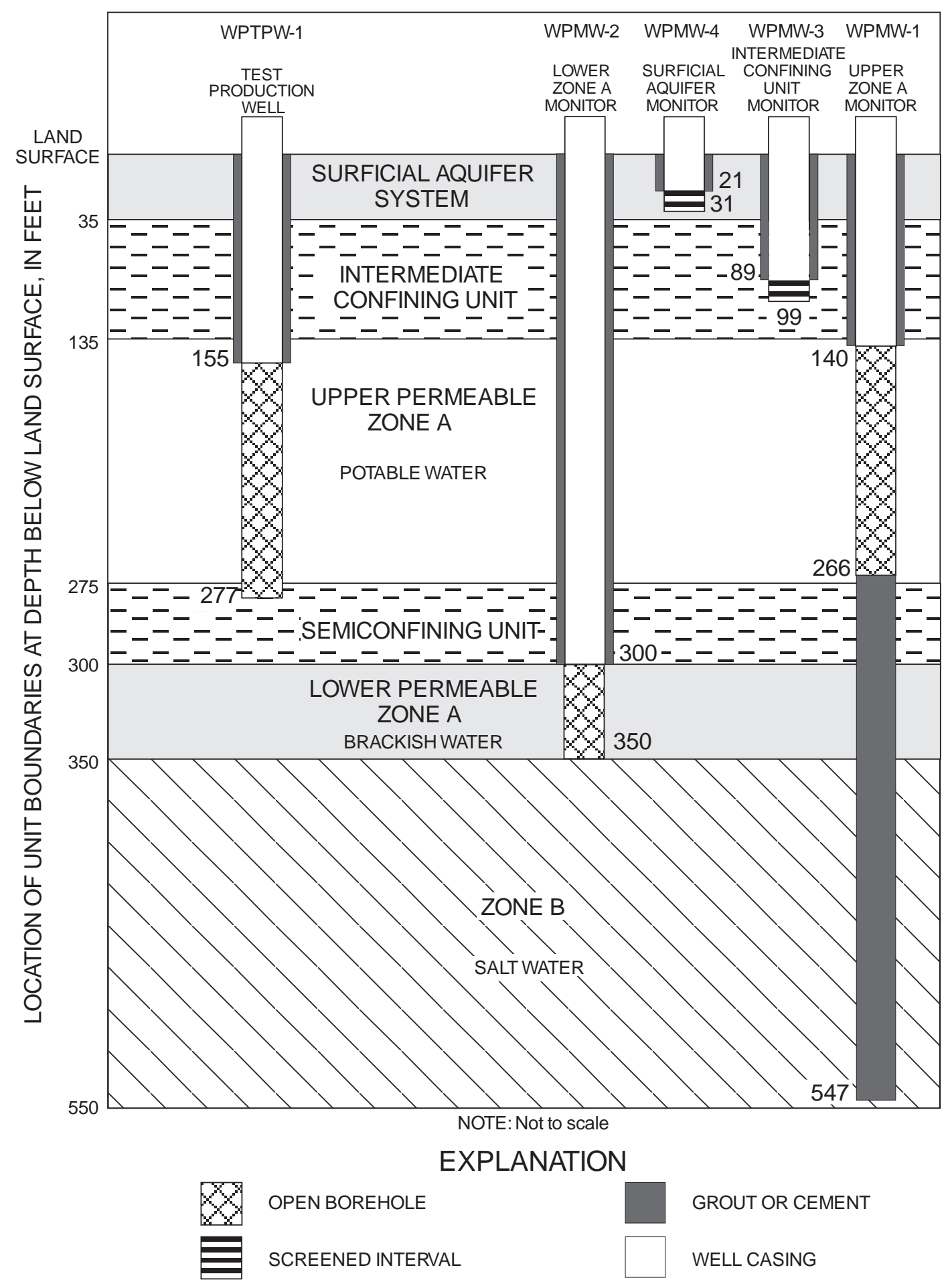

NOTE: Before backplugging to 266 feet, WPMW-1 was referred to as the deep exploratory well.

Figure 5. Generalized section view of casing depths and final depths of wells at the Walsingham Park test site. 


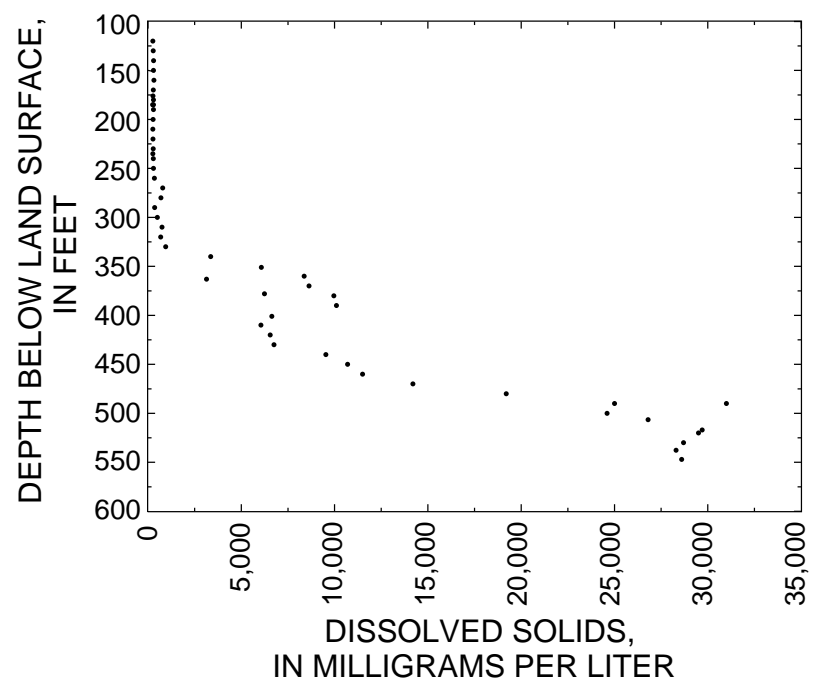

Figure 6. Relation of dissolved solids and depth from water samples collected during drilling of Walsingham Park deep exploratory well (WPMW-1).

The freshening of water samples between drilling days may have been the result of mixing of waters in the borehole. However, previous investigations in northern Pinellas County have shown that layering of water with higher dissolved-solids concentrations can occur over water with lower dissolved-solids concentrations (Knochenmus and Swenson, 1996). The nature of this water-quality anomaly at the Walsingham Park test site could not be determined upon completion of drilling.

Additionally, selected samples were used to show the correlation between specific conductance and dissolved-solids concentrations for ground water representative of the study site (fig. 7). The linear regression closely fits a straight line with a correlation coefficient (r) of 0.997. The correlation of the two parameters was later used to estimate changes in dissolved-solids concentration under pumping conditions; however, the relation of dissolved solids to specific conductance would not be constant for the entire range of samples (Hem, 1985). As figure 7 illustrates, the slope of the linear regression is different for specific ranges of conductance values. Changes in water quality that occurred during hydraulic testing are discussed further in the aquifer test section of this report.

\section{Geophysical Logging}

Borehole geophysical logging was used to delineate hydrogeologic units, flow zones, and waterquality changes at the test site. Geophysical logs were collected by a Pinellas County contractor under static and pumping conditions on WPMW-1. A lithologic log from WPMW-1 was also compiled during drilling.

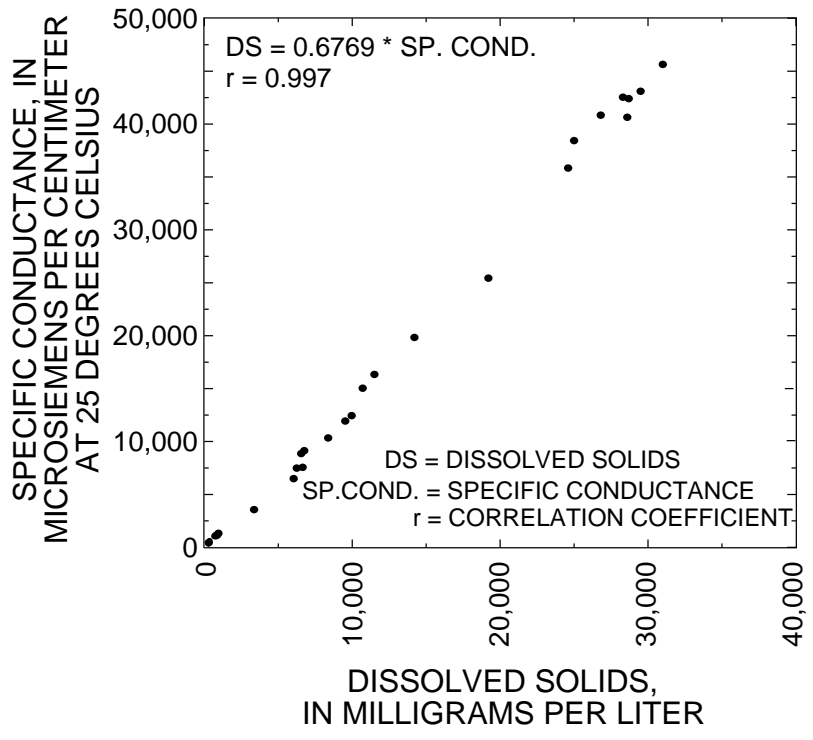

Figure 7. Relation between dissolved solids and specific conductance of selected water samples collected during drilling of Walsingham Park deep exploratory well (WPMW-1).

Logs collected during static conditions included caliper, natural-gamma radiation, fluid resistivity, and fluid temperature. Logs collected under pumping conditions included ascending and descending flow meter with the pump placed $120 \mathrm{ft}$ below land surface.

A schematic of the geophysical logs collected from WPMW-1 is shown in figure 8 .

Interpretations of the geophysical logs in conjunction with the lithologic log were used to determine the distribution of flow zones and semiconfining units. Natural-gamma radiation logs are used to delineate clay and phosphate-bearing deposits by recording the naturally occurring radiation coming from the formation adjacent to the borehole. The natural-gamma log, when correlated with the WPMW-1 lithologic log, confirmed the presence of clay and phosphate deposits from 35 to $135 \mathrm{ft}$ below land surface. This sequence corresponded to the ICU at the study site. The decrease in the natural-gamma values at about $340 \mathrm{ft}$ below land surface indicates a region of low phosphate content within the Suwannee Limestone.

Flow logs measured under pumping conditions are used in conjunction with caliper logs to delineate flow zones. Within a relatively uniform borehole diameter, an increase in counts per second indicates an increase in fluid velocity, thus an increase in flow. The flow meter logs collected at WPMW-1 indicate the presence of a major flow zone from around 300 to $350 \mathrm{ft}$ below land surface, corresponding to LZA. 


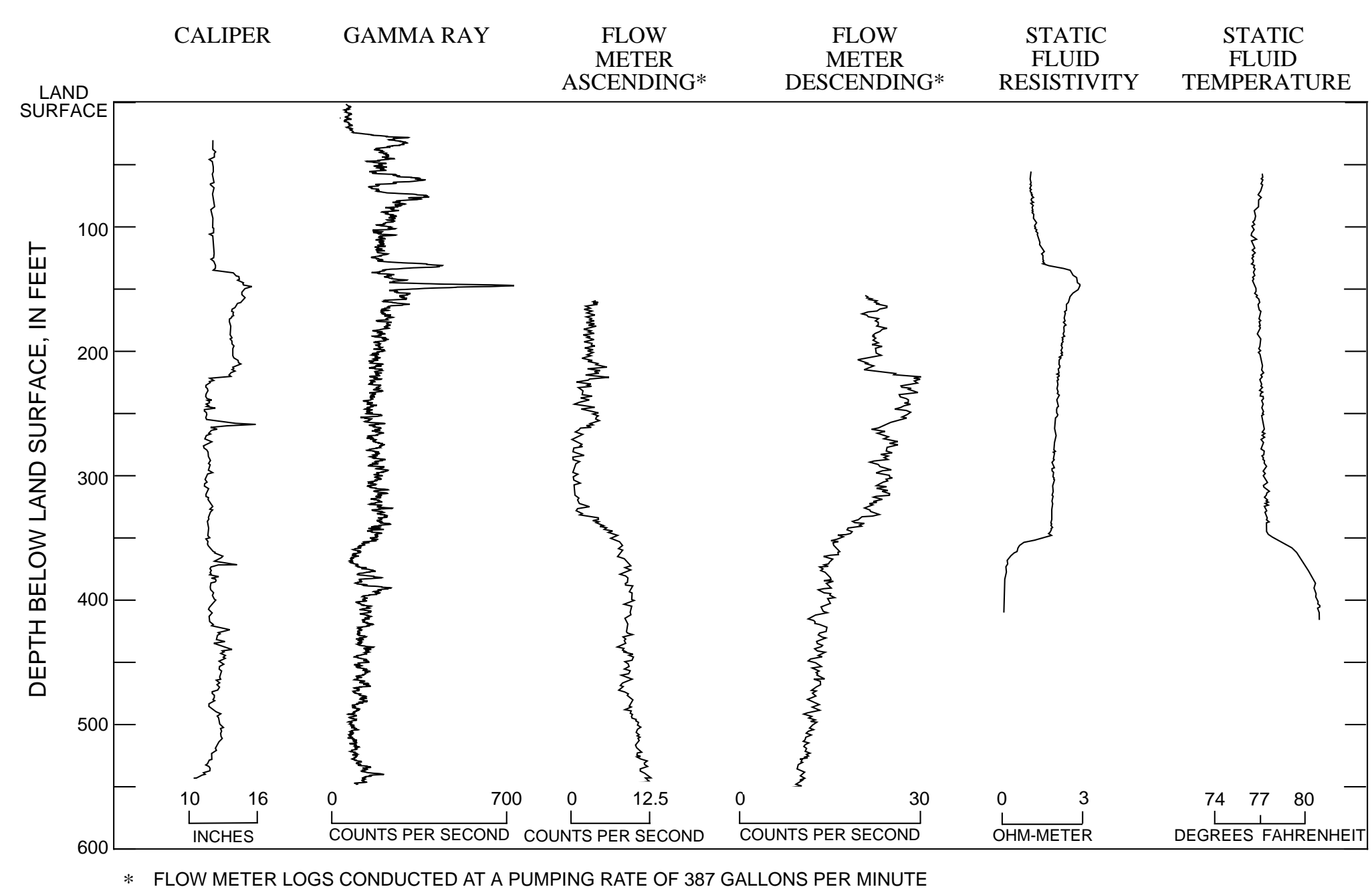

Figure 8. Geophysical logs of Walsingham Park deep exploratory well (WPMW-1). 
Fluid resistivity and temperature logs are used to identify zones of water-quality change. The fluid resistivity and fluid temperature logs indicate a rapid water-quality change approximately $350 \mathrm{ft}$ below land surface as fluid resistivity decreases and fluid temperature increases. The change in water quality at $350 \mathrm{ft}$ below land surface was noted in the water-quality profile developed from water samples taken during drilling. However, unlike the water-quality profile, neither the fluid resistivity nor temperature logs suggest a freshening of water from $360 \mathrm{ft}$ below land surface to the lowest extent of the logs at about $415 \mathrm{ft}$ below land surface (fig. 8).

\section{Specific-Capacity Tests}

Specific-capacity tests were performed on WPMW-1 to evaluate the various hydrogeologic units at the study site. Water-level data, collected under a range of pumping rates, were analyzed to estimate hydraulic parameters of the system. Specific-capacity tests measure well yield per unit of drawdown for specific intervals of individual hydrogeologic units. Results were used to estimate hydraulic properties of specific intervals, locate permeable zones, and determine the well and casing depths of the monitor and production wells. In addition to specific-capacity tests, packer tests were performed upon completion of WPMW-1 (prior to backplugging) to further identify permeable zones at the site. Transmissivity and hydraulic conductivity values, estimated from specific-capacity and packer tests performed on the deep exploratory well (WPMW-1), are listed in table 1.

Table 1. Results from specific capacity and packer tests from the deep exploratory well

[ft, feet; $\mathrm{ft}^{3} / \mathrm{d}$, cubic feet per day; (gal/min)/ft, gallons per minute per foot; $\mathrm{ft}^{2} / \mathrm{d}$, feet squared per day; $\mathrm{ft} / \mathrm{d}$, feet per day]

\begin{tabular}{cccccc}
\hline $\begin{array}{c}\text { Depth interval } \\
\text { below land } \\
\text { surface } \\
\text { (ft) }\end{array}$ & $\begin{array}{c}\text { Pump } \\
\text { rate } \\
\left(\mathbf{f t}^{\mathbf{3}} / \mathbf{d}\right)\end{array}$ & $\begin{array}{c}\text { Total } \\
\text { change } \\
\text { in head } \\
\mathbf{( f t )}\end{array}$ & $\begin{array}{c}\text { Specific } \\
\text { capacity } \\
(\mathbf{g a l} / \mathbf{m i n}) / \mathbf{f t}\end{array}$ & $\begin{array}{c}\text { Transmis- } \\
\text { sivity } \\
\left(\mathbf{f t}^{2} / \mathbf{d}\right)\end{array}$ & $\begin{array}{c}\text { Hydraulic } \\
\text { conductivity } \\
(\mathbf{f t} / \mathbf{d})\end{array}$ \\
\hline $135-185$ & 11,744 & 9.73 & 6.3 & 1,675 & 34 \\
$135-235$ & 11,934 & 8.87 & 7.0 & 1,870 & 19 \\
$135-235$ & 59,864 & 59.64 & 5.2 & 1,400 & 14 \\
$205-235$ & 9,336 & 9.59 & 5.1 & 1,350 & 45 \\
$230-282^{\mathrm{a}}$ & 17,901 & 13.74 & 6.8 & 1,810 & 35 \\
$268-285^{\mathrm{a}}$ & 9,182 & 4.63 & 10.3 & 2,750 & 162 \\
$288-340^{\mathrm{a}}$ & 18,289 & 14.50 & 6.6 & 1,750 & 34 \\
$338-355^{\mathrm{a}}$ & 9,624 & 4.31 & 11.6 & 3,100 & 182 \\
$385-542^{\mathrm{a}}$ & 9,124 & 5.77 & 8.2 & 2,195 & 33 \\
\hline
\end{tabular}

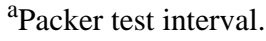

The values were estimated by applying specificcapacity and packer-test data to empirical equations developed from the modified Jacob nonequilibrium equation for a single-well test (Driscoll, 1986, p. 1021). Due to the difficulty in placing packers in the borehole and leakage problems detected around the packers, confidence in the packer-test data was low for determining hydraulic parameters. However, UZA from about 135 to $270 \mathrm{ft}$ below land surface and LZA from about 300 to $350 \mathrm{ft}$ below land surface were determined to be the primary flow zones contributing ground water to the wells. Although LZA had a higher specific capacity, it was located directly above a highly mineralized water-quality zone. Therefore, UZA was more suitable for a longer-term aquifer test.

\section{Aquifer Test}

A 9-day aquifer test was conducted at the test site from July 29 to August 7, 1997, to estimate the hydraulic parameters of Zone A and determine changes in water quality due to long-term pumping. The four onsite and one offsite monitor wells were used to observe responses in various zones to pumping from UZA at WPTPW-1. Background water-level data collected before and after pumping showed that head differences between zones at the test site reflected a downward head gradient (fig. 9). At the onset of the aquifer test, the water level in the SAS monitor (WPMW-4) was about $2.5 \mathrm{ft}$ above the water level in the ICU monitor (WPMW-3), whereas the water level in the ICU monitor was more than $36 \mathrm{ft}$ higher than the water level in the UZA monitor (WPMW-1).

Moreover, the water level in the UZA monitor was $0.15 \mathrm{ft}$ higher than the water level in the LZA monitor (WPMW-2). The test production well (WPTPW-1) was pumped at a rate of $220 \mathrm{gal} / \mathrm{min}$ for the length of the test. After the initiation of pumping, responses were noted for the various monitor wells. WPMW-1 responded immediately with a lowering of water level in the first minute of pumping. WPMW-2 also responded quickly with the first drawdown noted after 4 minutes of pumping. Contrasting the changes in water levels at these two wells, the water level in WPMW-1 decreased by $1.0 \mathrm{ft}$, whereas the water level in WPMW-2 decreased by $0.02 \mathrm{ft}$ after 4 minutes of pumping. Furthermore, a "reverse waterlevel fluctuation" (Andreasen and 


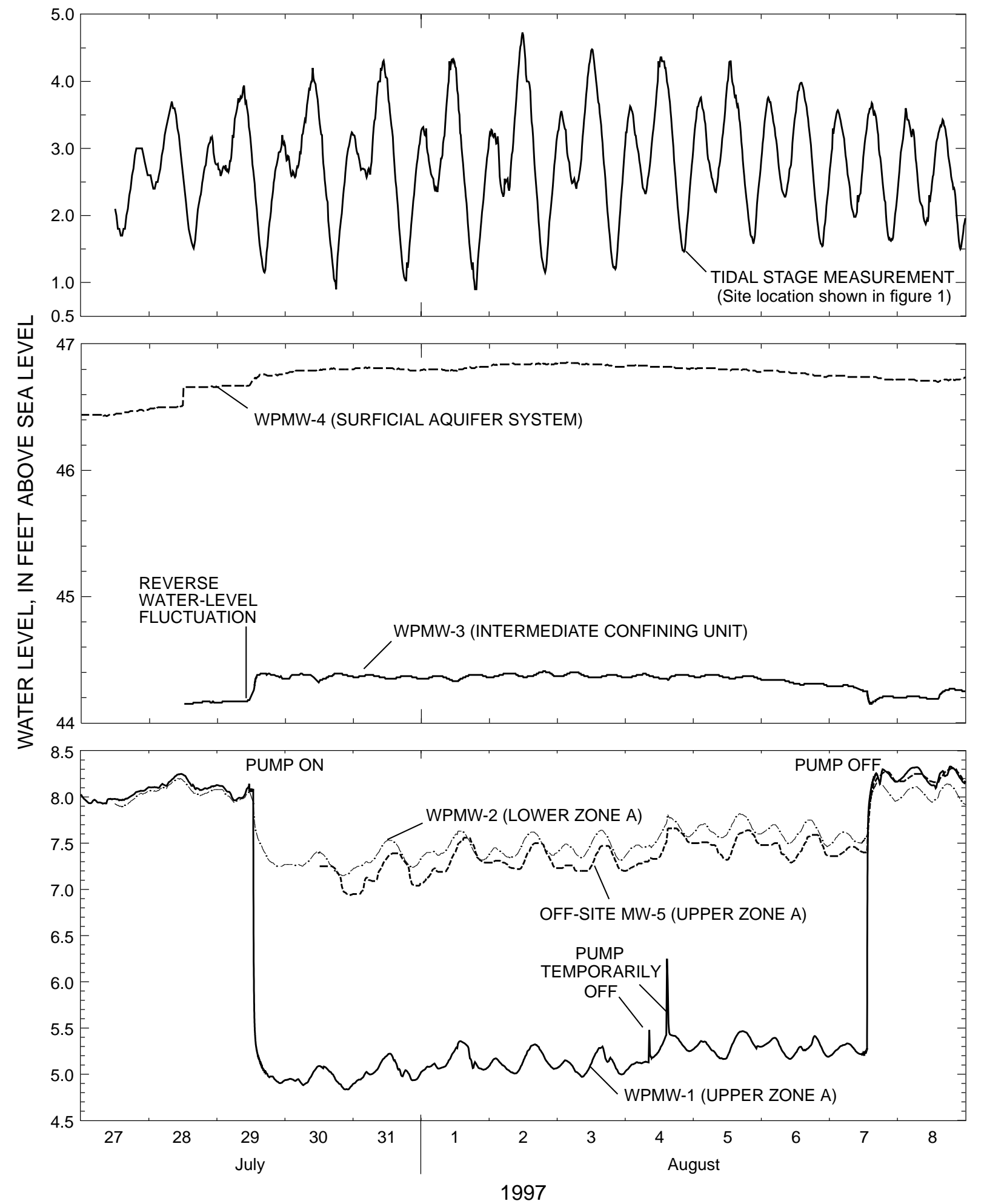

Figure 9. Water levels in all monitor wells before, during, and after the 9-day aquifer test. 
Brookhart, 1963) was observed in the ICU monitor well WPMW-3. The water level in the ICU began to rise immediately after pumping began and declined when pumping ended (fig. 9). A possible explanation for this occurrence is that the release of water from compressive storage produced by pumping in UZA caused a reduction in aquifer volume of UZA, which in turn caused both horizontal and vertical deformations in the overlying ICU. These deformations of the ICU subsequently induced the measured water-level rise. This phenomenon has been documented and is often referred to as the Noordbergum Effect (Hsieh, 1996). No response due to pumping was denoted in the surficial aquifer system monitor well WPMW-4. Although water levels were monitored in the five wells for the duration of the test, drawdowns reached steady-state within the first 3 hours of pumping when tidal effects began to interfere with drawdown measurements (fig. 9).

Water-quality data were collected for the duration of the 9-day aquifer test. Specific conductance probes were placed in WPMW-1 and WPMW-2 at depths of $250 \mathrm{ft}$ and $330 \mathrm{ft}$, respectively. Discharge water from WPTPW-1 was monitored hourly for specific conductance for the duration of the aquifer test. The changes in specific conductance measured during the test are shown in figure 10. Interestingly, waterquality changes noted in the UZA and the LZA monitor wells exhibited opposite trends. By using the relation between dissolved solids and specific conductance developed earlier (fig. 7), an inference can be made regarding the changes in dissolved solids concentrations during the aquifer test. The specific conductance in WPMW-1 in UZA increased from about 1,050 to $1,600 \mu \mathrm{S} / \mathrm{cm}$ corresponding to an increase in dissolved- solids concentration of about $372 \mathrm{mg} / \mathrm{L}$. By contrast, the specific conductance in WPMW-2 in LZA decreased from about 11,900 to $11,200 \mu \mathrm{S} / \mathrm{cm}$ corresponding to a decrease in dissolved-solids concentrations of about $440 \mathrm{mg} / \mathrm{L}$ over the 9 days of the test. The specific conductance of the composite sample collected from WPTPW-1 increased from 470 to $488 \mu \mathrm{S} / \mathrm{cm}$. Although this slight increase in measured specific conductance can be considered to be within the error of measurement of the conductance probe, the data showed a consistent trend (fig. 10).

The opposite trends in water-quality changes noted between the UZA and the LZA monitor wells during the 9-day aquifer test are difficult to explain.
The upward hydraulic gradient between LZA and UZA induced during the aquifer test may have resulted in upward movement of more saline water. However, the freshening of water in the LZA monitor well (WPMW-2) during the aquifer test is anomalous. As figure 10 illustrates, the rate of change of measured specific conductance appears to decrease from the time pumping began. It is possible that mineralized water may have invaded LZA during drilling of the deep exploratory well and may have evacuated LZA during the aquifer test, thus returning to native conditions. Since the aquifer test lasted only 9 days, no data are available to determine the specific conductance values at longer pumping times.

Data and the results of the aquifer test are on file and available at the USGS Tampa office. Because analytical methods are constrained by limitations in the simplification of a flow system into one- or twodimensional flow, the 9-day aquifer test was analyzed by using numerical methods. Numerical methods can simultaneously calculate changes in head and advective transport in a variable-density flow system for multiple observation points.

\section{ANALYSIS OF AQUIFER CHARACTERISTICS}

A numerical modeling approach was used to simulate the effects of pumping the variable-density ground-water flow system at the test site. The model was constructed to simulate the 9-day aquifer test conducted at the site and to refine estimates of hydraulic parameters such as hydraulic conductivity and storage coefficient determined from specific-capacity tests and previous investigations.

\section{Numerical Methods}

The USGS computer code HST3D (Kipp, 1987) was used to solve the equation for ground-water flow and solute transport using backward-in-space and backward-in-time finite-difference approximation methods. Mass-fractional concentrations and total fluid pressures were simulated using the model. The reader is referred to the original report that documents the computer code (Kipp, 1987) for a complete discussion of the numerical methods and model code. 


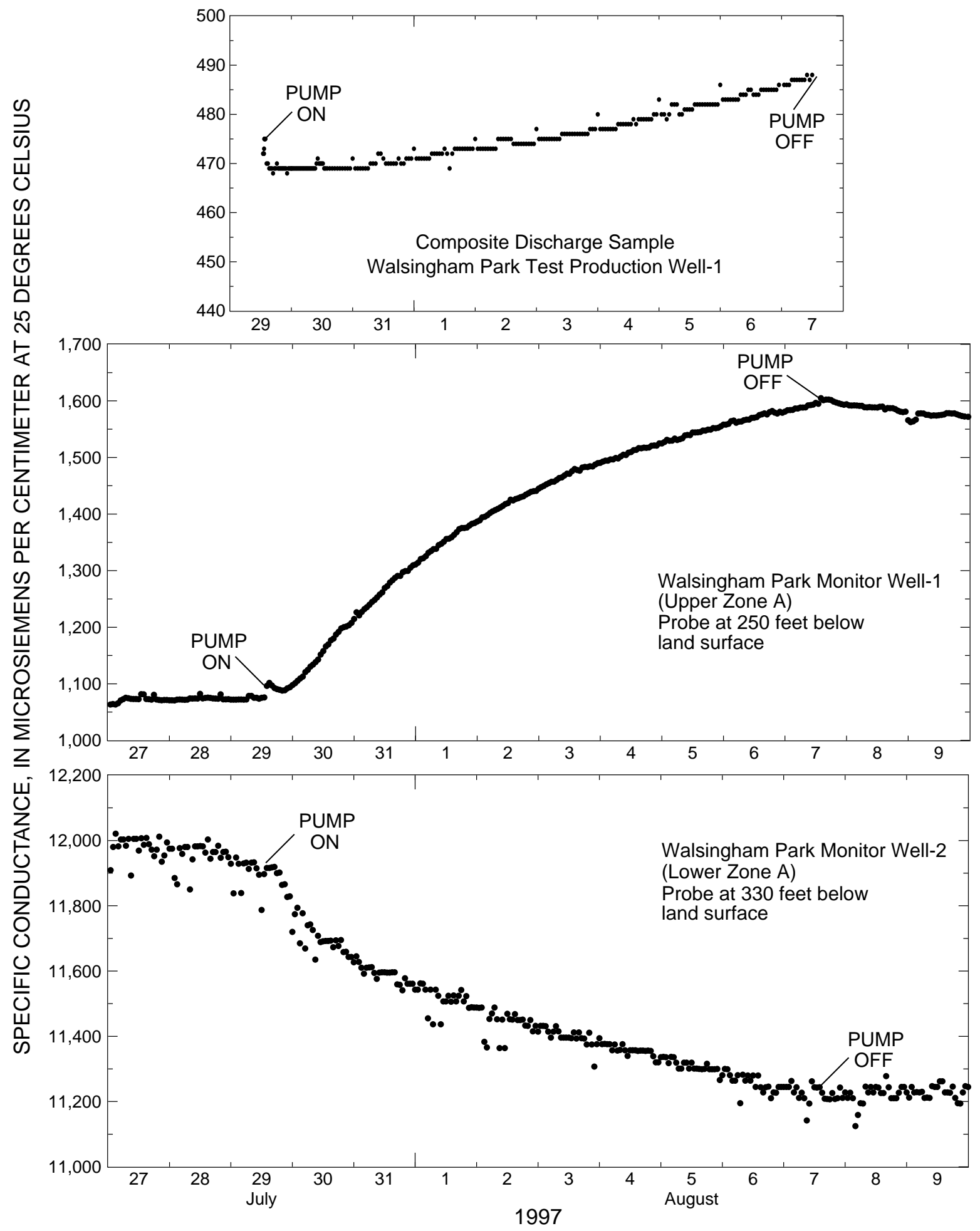

Figure 10. Changes in specific conductance during the 9-day aquifer test at Walsingham Park Test Production Well and Walsingham Park Monitor Wells 1 and 2. 


\section{Conceptual Model}

The hydrogeologic system of the study area is conceptualized as a multilayered aquifer system encompassing various permeable zones separated by confining and semiconfining units extending from the surficial aquifer system downward through the Suwannee Limestone of the Upper Floridan aquifer (fig. 2). Ground-water flow is considered to be lateral in permeable zones and vertical in confining and semiconfining zones. Ground-water quality changes from fresh to saline with depth as ground water becomes increasingly dense with higher concentrations of dissolved solids. Several assumptions were made regarding the conceptualized hydrogeologic system to effectuate numerical simulation:

1. The aquifer system is assumed to act as an equivalent porous medium,

2. All aquifer layers are homogeneous and isotropic,

3. Initial conditions are hydrostatic,

4. Initial fluid density is constant in each model row, and

5. The water-quality profile is laterally homogeneous for the entire model area.

\section{Design of Numerical Model}

The numerical model subdivides the conceptualized hydrogeologic system from the ICU through Zone B at the test site into an organized network of grid blocks, each with assigned fluid and matrix properties representing a 500-ft thick section underlying the test site. The model was constructed by using a cylindricalcoordinate grid of 124 columns and 12 rows (fig. 11), and was designed to simulate the responses of UZA and LZA to brackish-water development. The columns are variable in width with radial spacing expanding logarithmically from $0.3 \mathrm{ft}$ at the test production well up to a maximum width of $328 \mathrm{ft}$ extending out to $11,500 \mathrm{ft}$. Radial widths extending to 12,500 and $14,500 \mathrm{ft}$ were also simulated, but the additional simulation area in the horizontal direction had no affect on model results. The 12 model rows were grouped together as five distinct hydrogeologic layers. Layer 1 corresponds to model rows $1-3$, is $175 \mathrm{ft}$ thick, and represents Zone B of the Upper Floridan aquifer. Layer 2 corresponds to model rows 4 and 5 , is $50 \mathrm{ft}$ thick, and represents LZA of the Upper Floridan aquifer. Layer 3 corresponds to model row 6 and represents a discrete, 25 -ft section within Zone A with an increased occurrence of green clays. This section was modeled to determine the hydraulic properties of the unit separating UZA and LZA. Layer 4 corresponds to model rows $7-9$, is $150 \mathrm{ft}$ thick, and represents UZA of the Upper Floridan aquifer. Layer 5 corresponds to model rows $10-12$, is $100 \mathrm{ft}$ thick, and represents the ICU.

\section{Initial and Boundary Conditions}

Initial conditions refer to pressure and fluid property distributions established prior to the initiation of the model simulation. Hydrostatic conditions are established in HST3D from a distribution of dissolved solids and fluid densities for each model row. Values for dissolved-solids concentrations and fluid densities, based on water-quality parameters defined from samples taken during drilling, were used to establish initial conditions (table 2). The model calculates the starting fluid pressures based on the user-specified fluid property distribution for all model rows as well as at model boundaries. Under these hydrostatic conditions, the aquifer response to pumping is determined by model simulated changes in pressure relative to the initial hydrostatic conditions (Anderson and Woessner, 1992).

Boundary conditions delimit the model domain by constraining the lateral and vertical extent of the simulated flow system at the model periphery. The inner cylindrical boundary represents the production well and was defined by allocating well information to the various rows that represent the open-hole interval of the pumped well. Model rows not open to the production well were assigned a no-flow condition, whereas the outer cylindrical boundary was defined as a specified-pressure condition (fig. 11). The assigned pressure distribution along the vertical plane of the outer boundary was calculated by using water-level and dissolved-solids concentration data obtained during drilling of the test production well. The lower model boundary was defined as a specified-pressure boundary equivalent to the pressure exerted by a column of stratified saltwater and freshwater in the overlying strata determined from the density of water samples acquired during drilling (fig. 11). The outer and lower specified-boundaries were used to simulate an infinitely extensive aquifer while eliminating the modeling of indefinite regions outside the study area. The upper model boundary was assigned a no-flow boundary coinciding with the top of the ICU. Because no drawdown occurred in either the SAS or the ICU monitor wells during the aquifer test, a no-flow boundary condition at the top of the ICU was deemed appropriate. However, row 11 (corresponding to the 


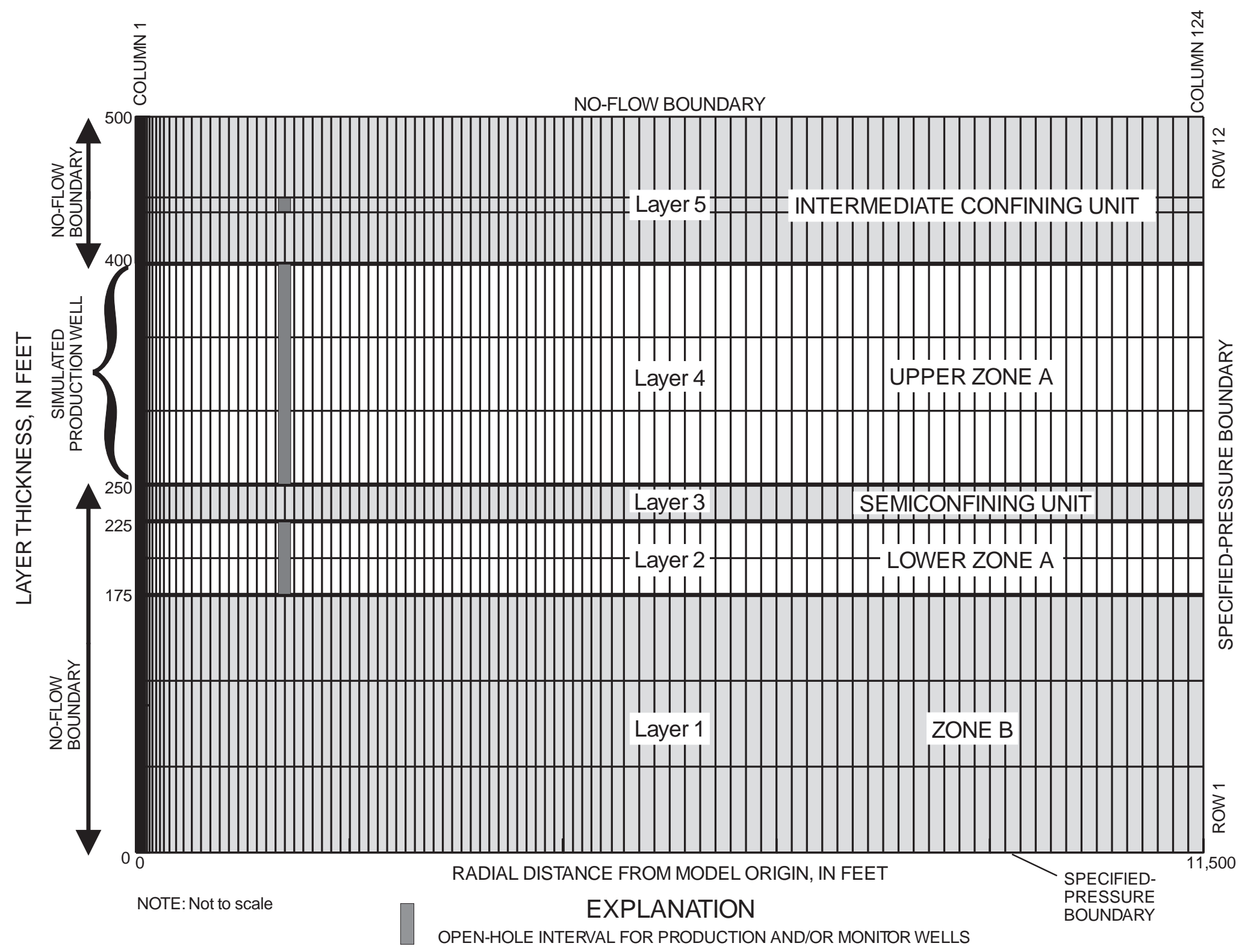

Figure 11. Model grid, simulated open-hole intervals, and boundary conditions used in the HST3D simulation. 
Table 2. Values for model parameters used to establish initial conditions and values for calibrated model parameters

[lb/ft ${ }^{3}$, pound per cubic foot; mg/L, milligrams per liter; $\mathrm{ft}^{2}$, feet squared; $\mathrm{ft} / \mathrm{d}$, feet per day]

\begin{tabular}{|c|c|c|c|c|c|}
\hline \multirow[b]{2}{*}{ Hydrogeologic unit } & \multicolumn{2}{|c|}{ Initial conditions } & \multicolumn{3}{|c|}{ Calibrated model } \\
\hline & $\begin{array}{l}\text { Density } \\
\left(\mathrm{lb} / \mathrm{ft}^{3}\right)\end{array}$ & $\begin{array}{c}\text { Scaled-solute } \\
\text { mass fraction / } \\
\text { dissolved solids } \\
(\mathrm{mg} / \mathrm{L})\end{array}$ & $\begin{array}{c}\text { Intrinsic } \\
\text { permeability }\left(\mathrm{ft}^{2}\right) / \\
\text { hydraulic } \\
\text { conductivity (ft/d) }\end{array}$ & $\begin{array}{l}\text { Storage } \\
\text { coefficient }\end{array}$ & $\begin{array}{l}\text { Effective } \\
\text { porosity } \\
\text { (percent) }\end{array}$ \\
\hline Intermediate confining unit & 62.38 & $0.0089 / 250$ & $3.9 \times 10^{-15} / 0.0001$ & $3.1 \times 10^{-4}$ & 35 \\
\hline Upper Zone A & 62.38 & $0.0098 / 275$ & $7.0 \times 10^{-11} / 18$ & $2.6 \times 10^{-4}$ & 30 \\
\hline Semiconfining unit & 62.41 & $0.0250 / 700$ & $3.9 \times 10^{-11} / 10$ & $4.3 \times 10^{-5}$ & 35 \\
\hline $\begin{array}{l}\text { Lower Zone } \mathrm{A}^{\mathrm{a}} \\
\quad(\text { Row 6) }\end{array}$ & 62.61 & $0.1786 / 5,000$ & $2.9 \times 10^{-9} / 750$ & $8.6 \times 10^{-5}$ & 30 \\
\hline $\begin{array}{l}\text { Lower Zone A } \\
\text { (Row 5) }\end{array}$ & 62.72 & $0.2679 / 7,500$ & $2.9 \times 10^{-9} / 750$ & $8.6 \times 10^{-5}$ & 30 \\
\hline Zone B & 63.65 & $1.0 / 28,000$ & $3.9 \times 10^{-12} / 1$ & $2.6 \times 10^{-5}$ & 30 \\
\hline
\end{tabular}

a Input parameters varied between the two rows representing Lower Zone A.

open-hole interval of WPMW-3) was used as an indictor for the upper limit of hydraulic parameters that would simulate a no-response condition in the ICU. Although the lack of a drawdown in the ICU made it impossible to accurately estimate hydraulic properties of the unit, model parameters in rows representing the ICU were adjusted to eliminate drawdown during the simulation.

\section{Model Parameters}

Model parameters including bulk matrix properties, fluid properties, and well information were defined for the five hydrogeologic units simulated (table 2). Although some adjustments were made to the parameters during calibration, initial values were carefully selected based on data collected during this investigation and previous studies (Hickey, 1982, 1989; Knochenmus and Swenson, 1996; Yobbi, 1996). Each model parameter is discussed in detail below:

\section{Bulk matrix properties.-Bulk matrix properties} include effective porosity, hydraulic conductivity (as a function of intrinsic permeability), storage coefficient (as a function of matrix compressibility), and dispersivity. Bulk matrix properties (except dispersivity) for each hydrogeologic layer are listed in table 2 . Because values of dispersivity are poorly known within the study area, a conservative approach was used by setting longitudinal and transverse dispersivity to zero.

2. Fluid properties._-Fluid properties include viscosity, density, compressibility, temperature, and dissolved-solids concentration. Dissolved-solids concentration is expressed as a scaled-solute mass fraction ranging from 0 to 1 in HST3D. A value of 0 represents pure freshwater whereas a value of 1 represents water with the highest dissolved-solids concentration $(28,000 \mathrm{mg} / \mathrm{L})$ in the model. Values for density and dissolved solids for each hydrogeologic layer are summarized in table 2. Fluid viscosity was held constant for the entire model at $1.0 \times 10^{-3}$ centipoise. Likewise, fluid temperature and fluid compressibility were held constant with values of $77^{\circ} \mathrm{F}$, and $3.03 \times 10^{-6} \mathrm{in}^{2} / \mathrm{lb}$, respectively.

3. Well information.-Well information needed for model input includes the withdrawal rate of the pumping well and is distributed equally over the three rows representing the pumped zone. The test production well open to UZA was simulated in model rows 7-9. The simulated pumpage was discretized with a constant withdrawal rate assigned to each of the three rows. The total pumpage assigned for all three rows for the aquifer test simulation equaled $220 \mathrm{gal} / \mathrm{min}$. Pumpage was varied thereafter from 200 to $700 \mathrm{gal} / \mathrm{min}$ during the brackish-water development simulations. 


\section{Simulation of Aquifer Test}

Numerical analysis of the 9-day aquifer test data provided a method for calculating hydraulic properties of various hydrogeologic units at the test site. The numerical model was calibrated by simulating the aquifer system's response to pumping UZA during the aquifer test. The model analysis of the 9-day aquifer test consisted of meeting two calibration objectives within acceptable limits: (1) simulate the drawdown and recovery of water levels in selected wells measured during the test, and (2) simulate the overall response of the system to pumping.

The first objective involved matching the initial drawdown part of the aquifer test. The initial 139 minutes of the aquifer test was used because nearly all drawdown effects occurred during this time and monitor well drawdowns could be separated from tidal effects. Tidal effect corrections were made by calculating the tidal efficiency for the monitor zone and adjusting drawdown and recovery data accordingly. Tidal efficiency is the ratio of the water-level amplitude measured in a well to the oceanic tidal amplitude (Ferris and others, 1962). Tidal data were collected at a gage located on the intracoastal waterway at Indian Rocks Beach, 2 mi west of the study site (fig. 1). The calculated tidal efficiency for Zone A averaged 10 percent for ebbing tides and 16 percent for flooding tides. After tidal corrections were made to the observed data, the corrected drawdowns were compared to simulated drawdowns.

Model parameters were adjusted until a reasonable match was derived where simulated drawdowns closely paralleled the observed drawdowns. A reasonable match was considered less than $0.10 \mathrm{ft}$ difference between simulated and observed drawdown data. Final calibrated values for hydraulic conductivity were 18 $\mathrm{ft} / \mathrm{d}$ for UZA, $750 \mathrm{ft} / \mathrm{d}$ for LZA, $1 \mathrm{ft} / \mathrm{d}$ for Zone B, $1 \times 10^{-4} \mathrm{ft} / \mathrm{d}$ for the ICU, and $10 \mathrm{ft} / \mathrm{d}$ for the semiconfining unit separating UZA and LZA. Final calibrated values for storage coefficient were $3.1 \times 10^{-4}$ for UZA, $8.6 \times 10^{-5}$ for LZA, $2.6 \times 10^{-5}$ for Zone B, $3.1 \times 10^{-4}$ for the ICU, and $4.3 \times 10^{-5}$ for the semiconfining unit separating UZA and LZA. Calibrated model parameters were further checked by comparing the observed recovery data of the aquifer test to the simulated recovery water levels (fig. 12). Values of the corrected, observed drawdown and recovery and simulated values are provided in table 3 .
Table 3. Simulated and corrected observed drawdown and recovery for selected monitor wells during the 9-day aquifer test

[UZA, upper zone A; LZA, lower zone A; NA, data not available; all values are in feet]

\begin{tabular}{lcccc}
\hline \multicolumn{1}{c}{$\begin{array}{c}\text { Zone } \\
\text { and } \\
\text { well }\end{array}$} & $\begin{array}{c}\text { Corrected } \\
\text { observed } \\
\text { drawdown }\end{array}$ & $\begin{array}{c}\text { Simulated } \\
\text { drawdown }\end{array}$ & $\begin{array}{c}\text { Corrected } \\
\text { observed } \\
\text { recovery }\end{array}$ & $\begin{array}{c}\text { Simu- } \\
\text { lated } \\
\text { recovery }\end{array}$ \\
\hline UZA & 2.69 & 2.66 & 2.79 & 2.66 \\
$\begin{array}{l}\text { WPMW-1 } \\
\text { LZA }\end{array}$ & 0.29 & 0.30 & 0.36 & 0.31 \\
WPMW-2 & NA & 0.59 & 0.54 & 0.60 \\
$\begin{array}{l}\text { UZA } \\
\text { Botanical Well }\end{array}$ & & & & \\
\hline
\end{tabular}

\footnotetext{
${ }^{\mathrm{a} C}$ Corrected drawdown for first 139 minutes of pumping.

${ }^{b}$ Corrected recovery for first 136 minutes of recovery in WPMW-1 and Botanical Well, and first 192 minutes of recovery in WPMW-2.
}

The second objective involved matching the long-term pattern of drawdown and recovery for the length of the 9-day aquifer test. As figure 9 shows, after the initial 139 minutes of pumping, observed drawdowns stabilized (excluding tidal effects) for the remainder of the 9-day test until the pump was turned off and recovery effects occurred. A reasonable match was accomplished when simulated drawdowns functioned in a similar fashion with drawdowns decreasing after the initial drop in water levels and stabilizing throughout the simulation until the recovery part of the test (fig. 13). It should be noted that the simulated hydrographs are superimposed over the uncorrected field hydrographs. No attempt was made to simulate the variations in water levels due to tidal effects.

\section{Sensitivity Analysis}

Sensitivity analysis was used to determine the effect of each parameter on the calibrated model results. Input parameters were individually varied over a reasonable range of values to determine the sensitivity of the model to that particular parameter over the entire simulation period. Ranges were based on values from previous investigations discussed in the hydrogeologic framework section of this report. Changes in certain parameters had no effect on the model, whereas others noticeably affected the model results. For example, a one order of magnitude increase and decrease in the value of matrix compressibility in model rows representing both UZA and LZA had no effect on the model results. Furthermore, a one order of magnitude increase and decrease in the intrinsic permeability of model rows representing the ICU had 

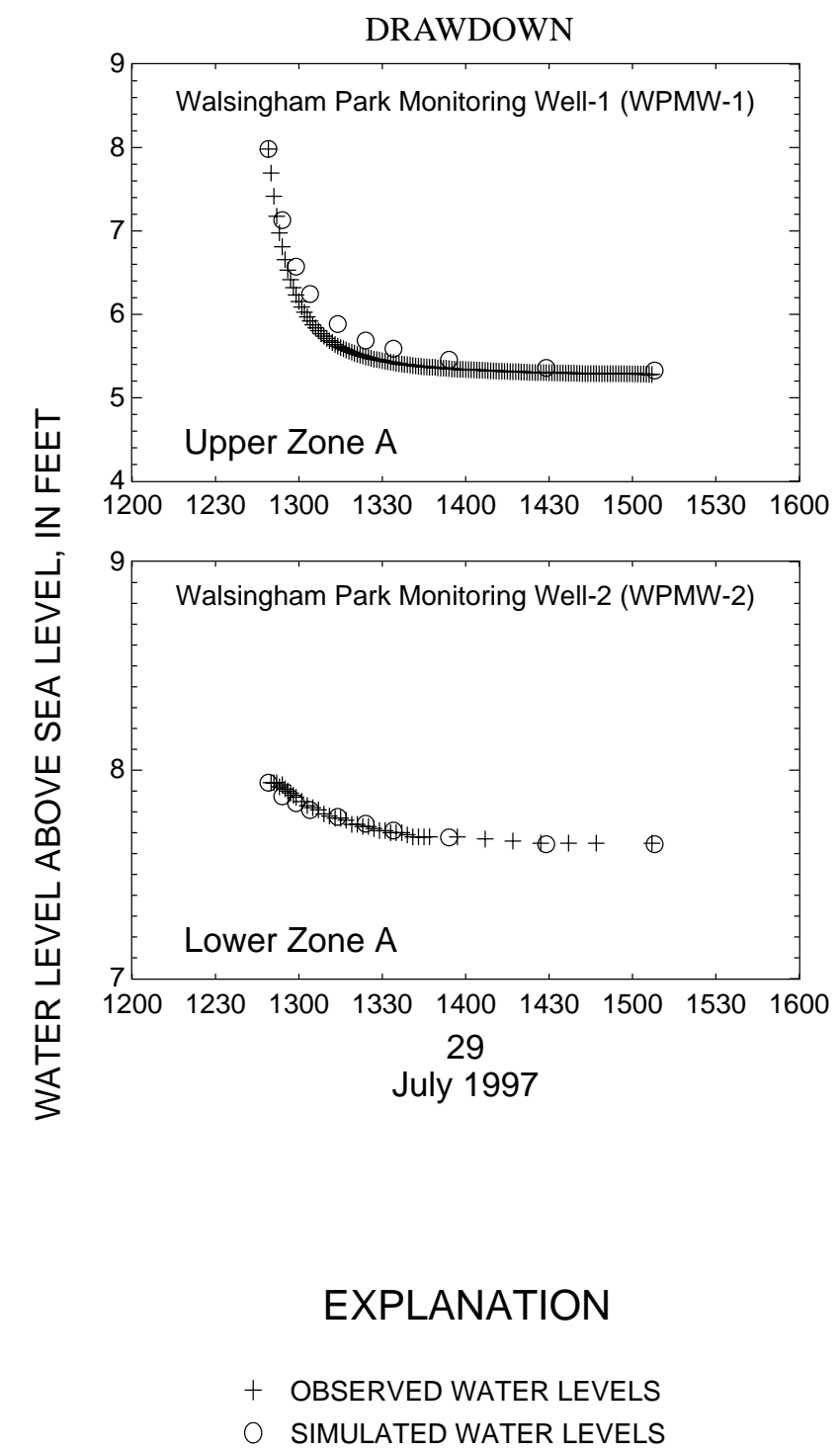

\section{EXPLANATION}

O SIMULATED WATER LEVELS
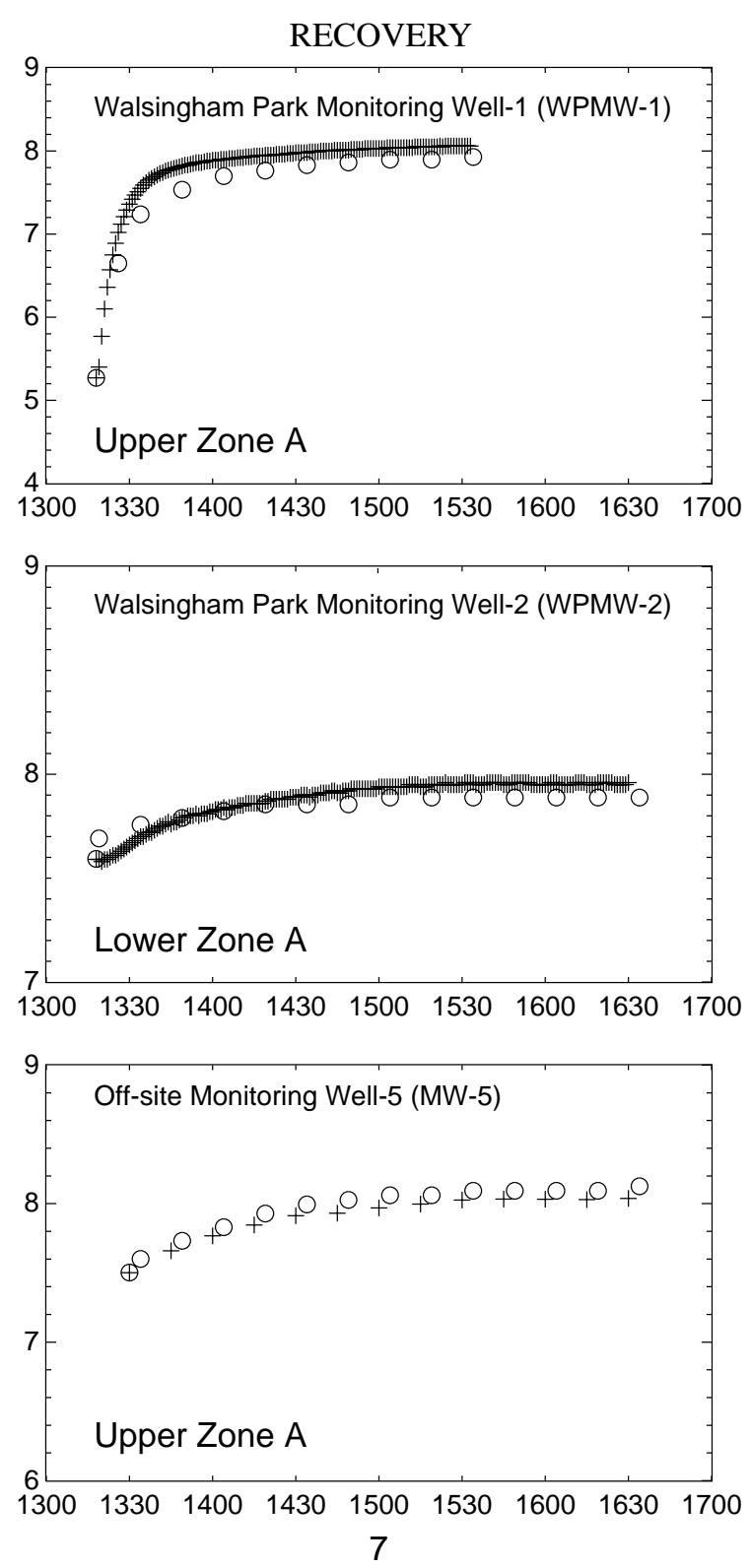

August 1997

Figure 12. Simulated and observed water levels during drawdown and recovery periods at selected wells during the 9-day aquifer test. 
no effect on the model results. Conversely, the largest changes to the model results occurred from changes in intrinsic permeability values assigned to both UZA and LZA (figs. 14a thru 14d). Model rows representing UZA were increased and decreased by one order of magnitude, whereas model rows representing LZA were changed by a factor of 2 and 0.5 . Additionally, the value of matrix compressibility assigned to model rows representing the ICU were increased and decreased by one order of magnitude (figs. 14e and 14f). An increase in the matrix compressibility of the ICU resulted in a slight response in only UZA. Furthermore, this response occurs in the early part of the drawdown graph, but the overall magnitude of drawdown in UZA did not change. The model was generally sensitive to changes of intrinsic permeability and insensitive to changes of matrix compressibility; therefore, more confidence was placed on estimates of transmissivity than on estimates of storativity.

\section{Model Limitations}

Results from model simulations outlined in this report are approximations of the actual hydrogeologic system. Confidence in model results is dependent on the assumptions outlined earlier in this report and the extent that the hydrogeologic system is simplified for mathematical representation. Simplification of the conceptual model is necessary to simulate a very complex natural system; however, the extent to which the system is simplified represents a source of error in model results. The major limiting factor in the model simulations is that the hydrogeologic system was simulated as a five-layered system with isotropic, homogeneous, and porous-medium individual layers. The actual hydrogeologic system may, however, be anisotropic, heterogeneous, and possess properties of secondary porosity due to dissolution and fracturing. Although alternate combinations of model parameters may provide similar results to those outlined in this report, the model incorporated the best estimates of the unknown parameters, the local geology, and hydrologic conditions.

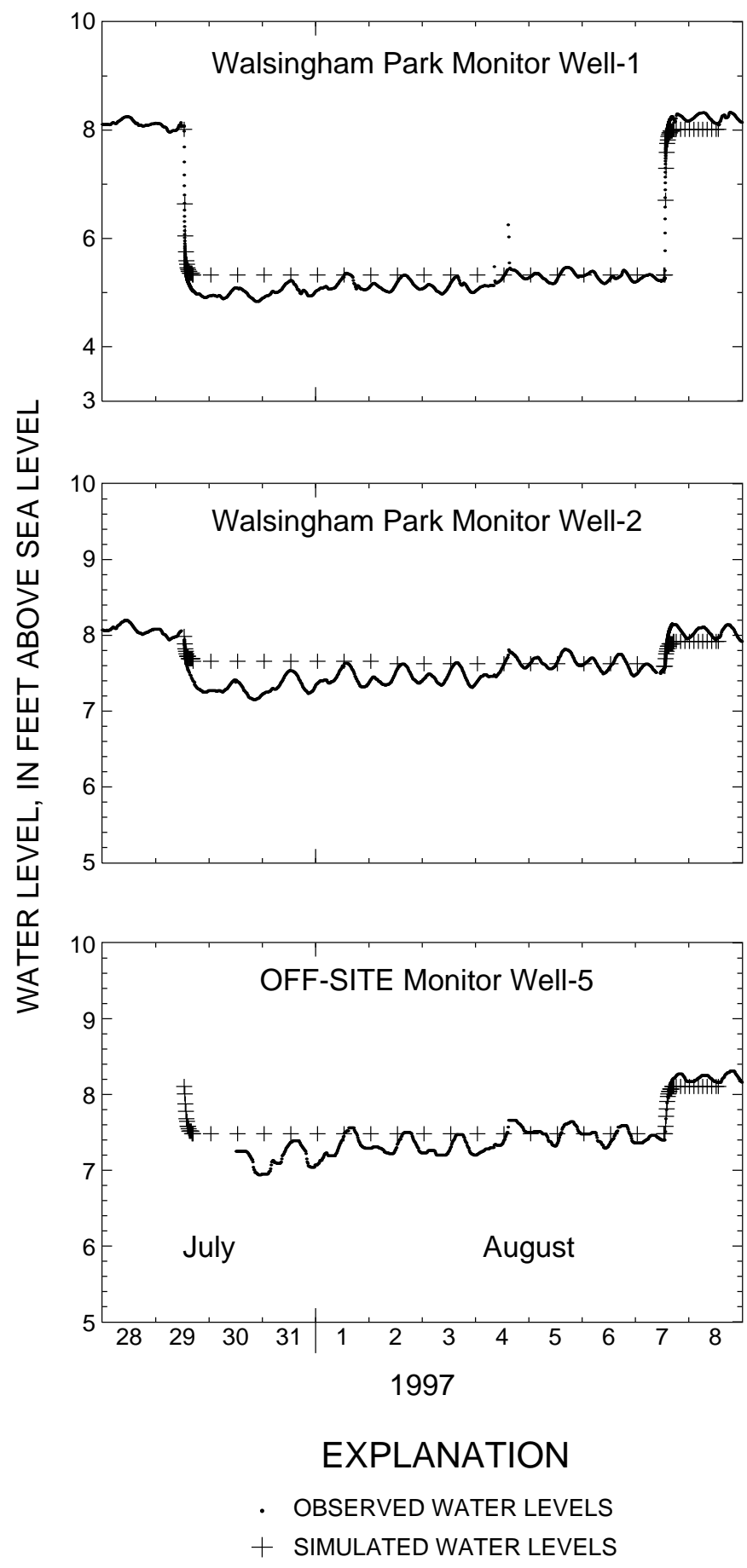

Figure 13. Simulated and observed water levels in selected monitor wells during the 9-day aquifer test. 
WPMW-1

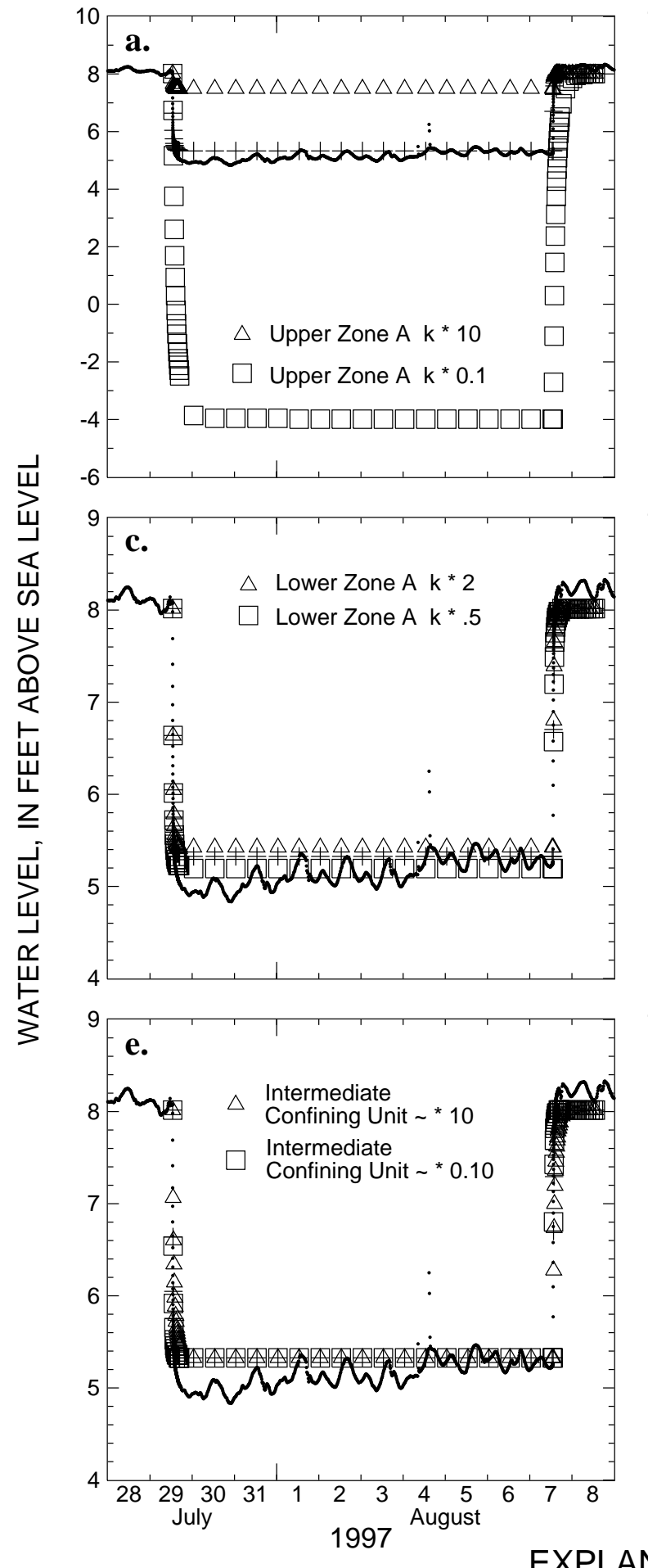

WPMW-2
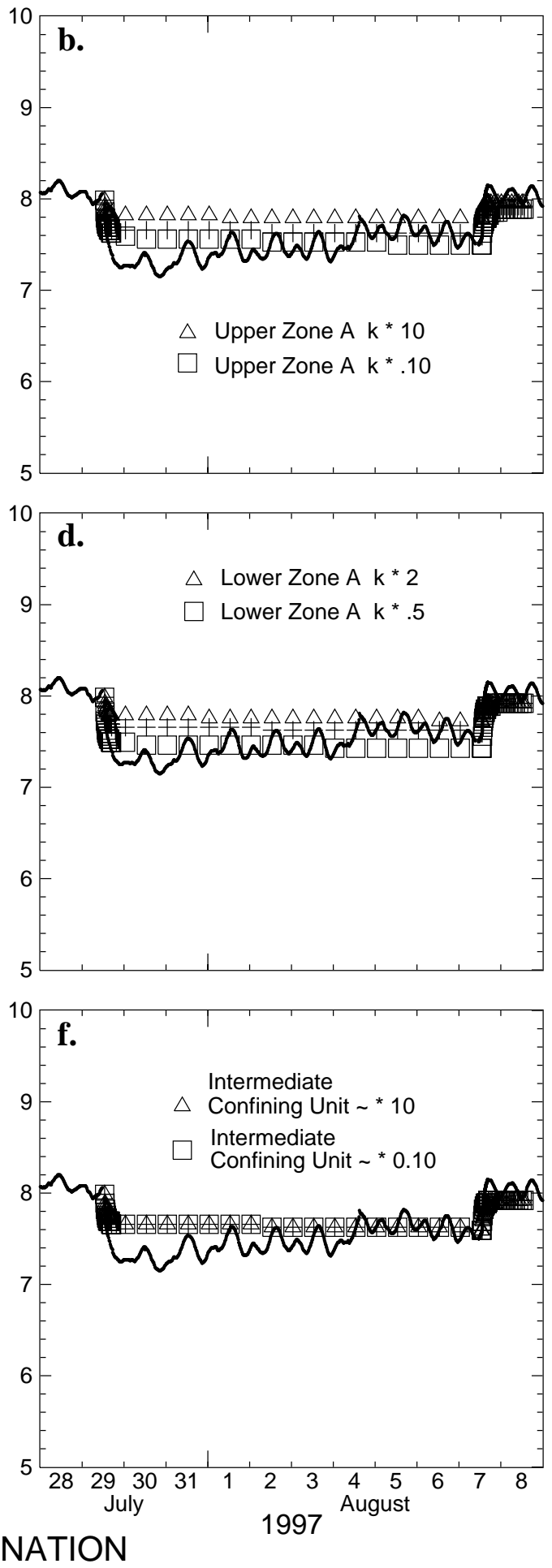

MATRIX COMPRESSIBILITY

k INTRINSIC PERMEABILITY

Figure 14. Sensitivity of simulated water levels to changes in selected model input parameters. 


\section{SUMMARY}

This report presents the results of a study to evaluate the brackish-water resources in the Upper Floridan aquifer underlying west-central Pinellas County, Florida. A production test well and four monitor wells were constructed at a location in Walsingham Park in 1996-97. The wells were sampled for waterquality parameters and investigated using borehole geophysical methods and hydraulic testing. The data collected were analyzed by using numerical techniques to delineate the hydrogeologic framework at the test site.

Collected data indicate that a multilayered aquifer system consisting of two permeable zones underlies Walsingham Park. One zone extends from about 135 to $275 \mathrm{ft}$ below land surface and corresponds to UZA of the Upper Floridan aquifer. Another permeable zone extends from about 300 to $350 \mathrm{ft}$ below land surface and corresponds to LZA of the Upper Floridan aquifer. Analysis of water-quality data indicates that LZA may not provide water of consistent quality because of rapidly increasing dissolved-solids concentrations occurring around $350 \mathrm{ft}$ below land surface. UZA was deemed more appropriate for production pumping and was tested during a 9-day aquifer test.

A numerical model was developed to simulate the 9-day aquifer test performed at the Walsingham Park test site. The model was calibrated to the drawdown and recovery water levels of selected monitor wells at the test site. Final calibrated values for hydraulic conductivity were $18 \mathrm{ft} / \mathrm{d}$ for UZA, $750 \mathrm{ft} / \mathrm{d}$ for LZA, $1 \mathrm{ft} / \mathrm{d}$ for Zone B, $1 \times 10^{-4} \mathrm{ft} / \mathrm{d}$ for the ICU, and $10 \mathrm{ft} / \mathrm{d}$ for the semiconfining unit separating UZA and LZA. Final calibrated values for storage coefficient were $3.1 \times 10^{-4}$ for UZA, $8.6 \times 10^{-5}$ for LZA, $2.6 \times 10^{-5}$ for Zone B, $3.1 \times 10^{-4}$ for the ICU, and $4.3 \times 10^{-5}$ for the semiconfining unit separating UZA and LZA.

\section{REFERENCES CITED}

Anderson, M.P., and Woessner, W.W., 1992, Applied groundwater modeling: Simulation of flow and advective transport: San Diego, Calif., Academic Press, $381 \mathrm{p}$.

Andreasen, G.E., and Brookhart, J.W., 1963, Reverse waterlevel fluctuations: Methods of collecting and interpreting ground-water data: U.S. Geological Survey WaterSupply Paper 1544-H, p. 30-35.

Black, Crow and Eidness, Inc., 1978, Drilling and testing of the monitoring and injection wells at the Southwest Wastewater Treatment Plant for the city of St. Petersburg, Florida: Brooksville, Consultant's report in the files of the Southwest Florida Water Management District.

Brown and Associates, Inc., 1986, Hydrological investigation for the development and management of the Floridan aquifer, city of Dunedin: Consultant's report in the files of the city of Dunedin, Florida

Causseaux, K.W., 1985, The surficial aquifer in Pinellas County, Florida: U.S. Geological Survey WaterResources Investigations Report 84-4289, 26 p.

Causseaux, K.W., and Fretwell, J.D., 1983, Chloride concentrations in the coastal margin of the Floridan aquifer, southwest Florida: U.S. Geological Survey WaterResources Investigations Report 82-4070, 33 p.

Cherry, R.N., and Brown, D.P., 1974, Hydrogeologic aspects of a proposed sanitary landfill near Old Tampa Bay, Florida: Florida Bureau of Geology Report of Investigations 68, $25 \mathrm{p}$.

Cherry, R.N., Stewart, J.W., and Mann, J.A., 1970, General hydrology of the middle Gulf area, Florida: Florida Bureau of Geology Report of Investigations 56, 96 p.

Driscoll, F.G., 1986, Groundwater and wells (2d ed.): St. Paul, Minn., Johnson Filtration Systems, Inc., 1089 p.

Ferris, J.G., Knowles, D.B., Brown, R.H., and Stallman, R.W., 1962, Theory of aquifer tests: U.S. Geological Survey Water-Supply Paper 1536-E, 174 p.

Gilboy, A.E., 1985, Hydrogeology of the Southwest Florida Water Management District: Southwest Florida Water Management District: Regional Analysis Section Technical Report 85-01, 18 p.

Heath, R.C., and Smith, P.C., 1954, Ground water resources of Pinellas County Florida: Florida Geological Survey Report of Investigations 12, 139 p.

Hem, J.D., 1985, Study and interpretation of the chemical characteristics of natural water: U.S. Geological Survey Water-Supply Paper 2254, 263 p.

Hickey, J.J., 1982, Hydrogeology and results of injection tests at waste-injection test sites in Pinellas County, Florida: U.S. Geological Survey Water Supply Paper 2183, $42 \mathrm{p}$. 
----- 1989, Circular convection during subsurface injection of liquid waste, St. Petersburg, Florida: Water Resources Research, v. 25, no. 7, 1481-1494 p.

Hsieh, P.A., 1996, Deformation-induced changes in hydraulic head during ground-water withdrawal: Ground Water, v. 34, no. 6, p. 1082-1089.

Hutchinson, C.B., and Stewart, J.W., 1978, Geohydrologic evaluation of a landfill in a coastal area, St. Petersburg, Florida: U.S. Geological Survey Water-Resources Investigations Report 77-78, 40 p.

Kipp, K.L., Jr., 1987, HST3D: A computer code for simulation of heat and solute transport in three-dimensional ground-water flow systems: U.S. Geological Survey Water-Resources Investigations Report 86-4095, 519 p.

Knochenmus, L.A., and Swenson, E.S., 1996, Assessment of the fresh- and brackish-water resources underlying Dunedin, Florida: U.S. Geological Survey WaterResources Investigations Report 96-4164, 40 p.

Marella, R.L., 1992, Water withdrawals, use, and trends in Florida: U.S. Geological Survey Water-Resources Investigations Report 92-4140, 38 p.
Miller, J.A., 1986, Hydrogeologic framework of the Floridan aquifer system in Florida and in parts of Georgia, Alabama, and South Carolina: U.S. Geological Survey Professional Paper 1403-B, 91 p.

Seaburn and Robertson, Inc., 1983, Results of the hydrologic testing program for the city of Clearwater water supply investigation: Consultant's report in the files of the city of Clearwater.

Sinclair, W.C., 1974, Hydrogeologic characteristics of the surficial aquifer in northwest Hillsborough County, Florida: Florida Bureau of Geology Information Circu$\operatorname{lar} 86,98 \mathrm{p}$.

University of Florida, 1991, Florida population: Census summary 1990: Gainesville, University of Florida, Bureau of Economic and Business Research, 55 p.

White, W.A., 1970, The geomorphology of the Florida Peninsula: Florida Bureau of Geology Bulletin 51, 164 p.

Yobbi, D.K., 1996, Simulation of subsurface storage and recovery of treated effluent injected in a saline aquifer, St. Petersburg, Florida: U.S. Geological Survey WaterResources Investigations Report 95-4271, 29 p. 